\title{
Tectonics of SE China: New insights from the Lushan massif (Jiangxi Province)
}

\author{
Wei Lin, ${ }^{1}$ Michel Faure, ${ }^{1}$ Patrick Monié, ${ }^{2}$ Urs Schärer, ${ }^{3}$ \\ Liangsheng Zhang, ${ }^{3}$ and Yan Sun ${ }^{4}$
}

\begin{abstract}
In south China the Lushan massif forms a topographic high of the South China Block south of the Qinling-Dabie belt. The Lushan massif consists of two main lithotectonic units separated by a major tectonic contact: a Neoproterozoic (upper Sinian)-Paleozoic unit comprising primarily unmetamorphosed sandstones overlies a Paleoproterozoic unit mainly composed of low-pressure, high-temperature gneisses and micaschists. Both units are cut by Cretaceous granitic intrusions. Three primary tectonometamorphic and magmatic events are recognized. The eastern part of the Lushan massif is cut by a NNE-SSW trending ductile normal fault (D3 deformation) coeval to the emplacement of a 100-110 Ma leucogranite dated by ${ }^{40} \mathrm{Ar} /{ }^{39} \mathrm{Ar}$ laserprobe on biotite and muscovite. D2 deformation is responsible for the formation of a decakilometer-scale NE-SW trending upright anticline characterized by NE-SW stretching and NW-SE shortening. The age of this folding event is defined by a $127 \pm 1(2 \sigma) \mathrm{Ma}$ $\mathrm{U} / \mathrm{Pb}$ titanite date obtained for a syntectonic granodiorite and ${ }^{40} \mathrm{Ar} /{ }^{39} \mathrm{Ar}$ ages of $133 \mathrm{Ma}$ for amphibole. This Cretaceous age also corresponds to the ${ }^{40} \mathrm{Ar} /{ }^{39} \mathrm{Ar}$ ages of $126 \mathrm{Ma}$ found on syntectonic muscovites at the base of the Sinian unit. An older deformation event, D1, characterized by a top-to-theNW extensional decollement of the Sinian-Paleozoic series above Proterozoic metamorphic rocks is related to the Triassic tectonics of the Dabieshan. Lastly, in the lower part of Sinian rocks, the occurrence of kyanite cataclased during D1 documents an older, poorly preserved, late Paleozoic-early Mesozoic tectonometamorphic event (Dx) related to a blind thrust in the continental crust of the South China Block in the southern foreland of the Dabieshan.
\end{abstract}

\section{Introduction}

East China formed by welding of two continents, namely, the North China and South China Blocks, along the QinlingDabie belt. Timing of collision and continued convergence is not yet settled. The deformation ranges from early Paleozoic to

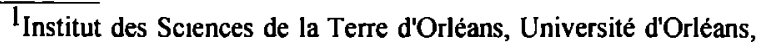
Orléans, France.

${ }^{2}$ Laboratoire de Géochronologie, Géochimie et Pétrologie, Université de Montpellıer 2, Montpellier, France.

${ }^{3}$ Laboratoire de Géochronologie, Université Paris 7, Paris.

${ }^{4}$ Department of Earth Sciences, Nanjing University, Nanjıng, China.
}

Copyright 2000 by the American Geophysical Union.

Paper number 2000TC900009.

$0278-7407 / 00 / 2000 \mathrm{TC} 900009 \$ 12.00$
Jurassic through Early Triassic [e. g., Mattauer et al., 1985, 1991; Okay et al., 1993; Hacker et al., 1996; Gilder et al., 1999]. The north directed continental subduction of south China was responsible for ultra-high pressure (UHP) metamorphism and related deformation in the Dabieshan. Several interpretations have been put forward to account for the geodynamic evolution of the Qinling-Dabie belt, but whatever the proposed model, the southern foreland of the Dabieshan is seldom considered. Since it is likely that such intense deformation as that related to UHP metamorphism should also exert a strong influence on the structural evolution of the South China Block south of the collision zone, we have conducted the first detailed structural and geochronologic investigations of the metamorphic rocks of the Lushan massif, which is a key element for the understanding of the Mesozoic evolution of south China.

While tectonic evolution of South China is generally poorly understood, in Jiangxi Province, south of the Dabieshan, three basement areas are recognized: the Wugongshan, Jiulingshan, and Lushan massifs from south to north respectively (Figure 1). The Jiulingshan anticline consists of Proterozoic slates, phyllites, and granitoids, overlain by sedimentary rocks ranging from latest Proterozoic (Sinian) to Early Triassic. Locally, along the south margin of the anticline, the tectonic superposition of phyllites upon Triassic or Permian limestones was previously invoked as evidence for large-scale overthrusting [Hsü et al., 1990]. This interpretation is superseded by a mechanism of extensional shearing, indicated by displacement of the allochthonous rocks top-to-the-south and top-to-the-north along the south and north margins, respectively; this allochthonous association is best explained in terms of extensional shearing of previously folded layers [Lin et al., 1998; Faure et al., 1998]. The Wugongshan massif is a metamorphic dome formed in an extensional setting during two tectonic and plutonic events [Faure et al., 1996]. The major event was responsible for top-to-the-south and top-to-the-north ductile shearing along the south and north margins, respectively (Figure 1). Argon 40/Argon 39 dating of synkinematic biotite and muscovite yields ages of 225-230 Ma (Early Triassic) for this extensional phase. The second phase corresponds to the emplacement of an Early Cretaceous (circa $130 \mathrm{Ma}$ ) granodiorite responsible for amplification of the domal shape and local mylonitization along the pluton margins.

At the northern border of Jiangxi Province, south of the Changjiang, the Lushan massif (Figure 1) is the smallest of these basement highs. There also, a northward transported klippe structure has been proposed [Hsü et al., 1990]. This paper presents a detailed structural analysis of the Lushan massif with new geochronological constraints provided by 


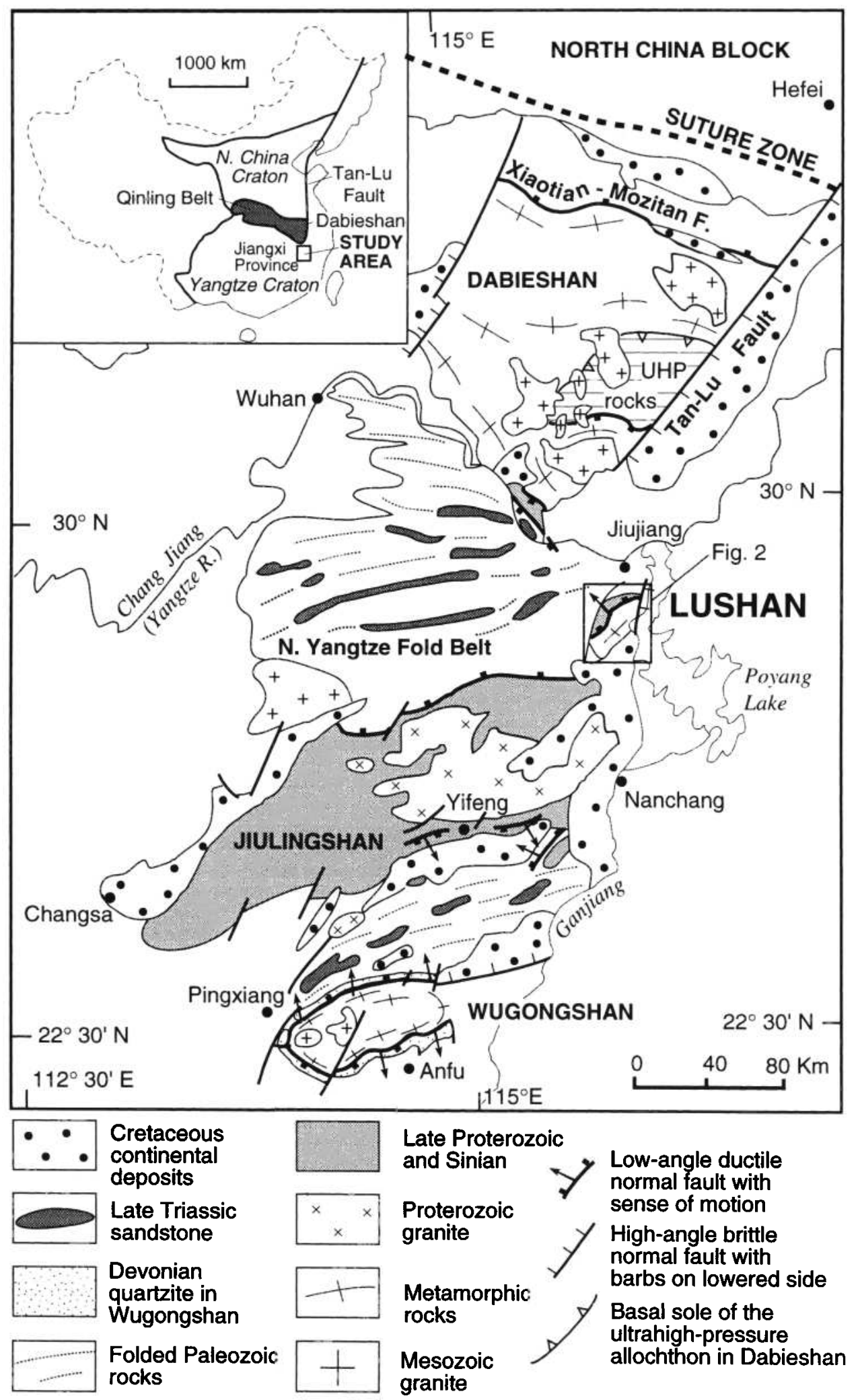

Figure 1. Structural map of the south China platform south of Dabieshan showing the study area. UHP, ultrahigh pressure. 


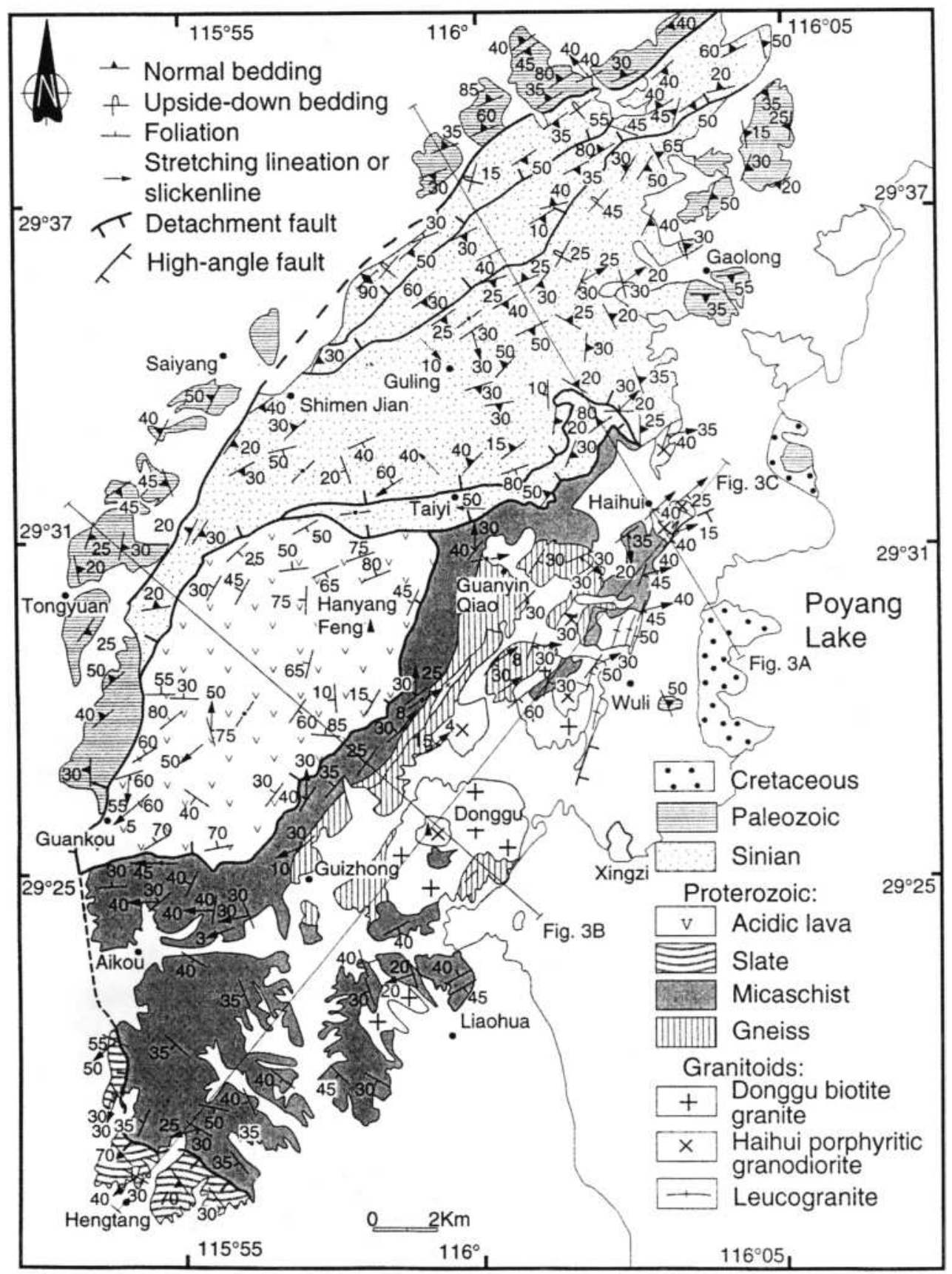

Figure 2. Geological and structural map of the Lushan massif.

${ }^{40} \mathrm{Ar} /{ }^{39} \mathrm{Ar}$ and $\mathrm{U} / \mathrm{Pb}$ data. These results are discussed in the tectonic framework of SE China, indicating that the south China basement was also involved in synmetamorphic thrusting and subsequent extension coeval to the collisional tectonics of the Dabieshan.

\section{Geological Overview of the Lushan Massif}

A wide variety of rock types is exposed in the Lushan massif including sedimentary rocks, high-grade metamorphics, plutonics and volcanics [Jiangxi Bureau of Geology and
Mineral Resources (JBGMR), 1984]. Although rare Cretaceous red beds occur near Poyang Lake, most of the sedimentary rocks belong to Late Proterozoic and Paleozoic series (Figure 2). In the western and NE parts of the massif, Paleozoic rocks, devoid of metamorphism, consist of terrigenous facies (sandstone and siltstone) of SilurianOrdovician age and rare Cambrian carbonates. In Lushan the highest peaks are made of thick (nearly $800 \mathrm{~m}$ ) coarse-grained sandstones, with conglomeratic and pelitic interbeds of Late Proterozoic (Sinian) age. To the south and east, this sequence is underlain by slates and acidic volcanics of Middle 
Proterozoic age which regionally are included in the "Banxi group" [JBGMR, 1984]. Middle Proterozoic rocks are missing in the NE part of the Lushan massif, and the Sinian sedimentary rocks instead directly overlie high-grade metamorphic rocks. This lack of Middle Proterozoic rocks is not due to a stratigraphic gap but rather to a tectonic discontinuity as argued below. Proterozoic slates, in tum, are underlain by biotite-garnet-staurolite micaschists. Amphibolites, quartzites, and conglomerates are also found in a limited amount, thus in Figure 2 they are grouped with the micaschists or gneisses. In micaschists, widespread staurolite crystals are generally retrogressed to fine-grained white mica (sericite). The central part of the Lushan massif is occupied by $\mathrm{K}$-feldspar gneisses and biotite-muscovite gneisses. Intense recrystallization of these rocks precludes recognition of precursor lithologies; an igneous (granitic) or a sedimentary protolith is equally likely. Although detailed chemical analysis or thermobarometry of the metamorphic assemblages has not been investigated, the conspicuous occurrence of biotite-garnet-staurolite in micaschist and biotite-muscovitegarnet in gneiss indicates that the Lushan metamorphic rocks belong to an intermediate temperature-intermediate pressure type. As discussed in section 3, occurrence of muscovite and kyanite in the lower part of the Sinian sedimentary sequence shows that metamorphism decreases upwards from the basal gneiss and disappears within the Sinian rocks. This geometry is in agreement with the interpretation of a normal metamorphic succession with the lower part of higher metamorphic grade than the upper part [JBGMR, 1984].

Three types of plutonic rocks are found in the study area. The main lithology is a medium-grained biotite granite mined in Mount Donggu (Figure 2). In the field no preferred orientation of minerals is observed in this granite. Another rock type, well exposed near Haihui, is a biotite-hornblende porphyritic granodiorite with abundant microgranular mafic enclaves. By contrast with the Donggu granite, the Haihui granodiorite exhibits a well-marked planar and linear preferred orientation of biotite, plagioclase, and microgranular enclaves. Lastly, leucogranite outcrops around Wuli in the eastern part of the Lushan massif (Figure 2). This leucogranite contains xenoliths of the Haihui granodiorite. As discussed in section 3, the leucogranite shows well-developed, penetrative, post-solidus foliation and lineation. In addition to these three types of plutonic rocks, numerous pegmatitic and granitic dikes crosscut the metamorphic rocks and the basal part of the Sinian sandstone series.

\section{Polyphase Deformation}

Our structural survey of the Lushan massif allows us to recognize its bulk geometry and to unravel three successive deformation episodes. Bedding is preserved only in Sinian to Paleozoic rocks and occasionally in Proterozoic slates; in contrast, the reference surface in the micaschists and gneisses is the metamorphic foliation. The systematic measurement of the planar structures (bedding, slaty cleavage, and foliation) shows that the Lushan massif has an antiformal, NE-SW elongated shape with its eastern side downfaulted below Poyang Lake (Figures 2, and 3). Although dominantly NESW trending, the planar structure progressively turns NW-SE at the SW and NE margins of the Lushan massif (Figure 4). Geometrically, the Lushan massif might be considered either as a "dome" or as a brachyanticline; however, is it worth noting that the Donggu pluton does not strictly occupy the hinge part of the antiform but lies slightly eastward of the fold hinge (Figures 2, and 3). This geometry suggests that folding preceded granite intrusion. The above succession, namely, from top to bottom, Paleozoic sedimentary rocks, Sinian clastics, Proterozoic slate, and volcanics and metamorphic rocks, corresponds to a stack of tectonostratigraphic units (Figure 3). The boundary between Paleozoic and Sinian sedimentary rocks is a subvertical fault which is probably reworked during Cretaceous or younger events as suggested by the local occurrence of fault breccia. In agreement with geological mapping [JBGMR, 1984] the boundaries between Sinian, Late Proterozoic, and micaschists are not primary stratigraphic contacts but tectonically reworked. We describe in sections 3.1-3.3 three ductile deformation phases, D1-D3, from youngest to oldest.

\subsection{D3 Deformation}

The D3 event, restricted to the eastern side of the Lushan massif, is observed in the leucogranite in the form of S-C mylonites characterized by a SE dipping shear plane (S3) and an ENE-WSW $\left(45^{\circ} \mathrm{N}-\mathrm{N} 90^{\circ} \mathrm{E}\right)$ stretching lineation, L3 (Figure 4). The latter is better called a "high-temperature slickenline" since it is observed on the $C$ shear plane and not on the $S$ foliation surface (Figure 4). S-C relationships, sigmoidal muscovite flakes, $\sigma$-type porphyroclast systems of feldspathic clasts, and recrystallized grain shape fabric in quartz ribbons indicate a normal sense of motion with the eastern side moving down with a sinistral wrench component (Figure 5). This D3 S-C mylonitic foliation is also deformed by downward, overturned, postfolial folds, kinematically consistent with the shearing that lead to the S-C mylonite development. This D3 deformation occurs along a $6-\mathrm{km}$-long linear belt and is interpreted here as a ductile normal fault located at the eastern boundary of the Lushan massif, near the Poyang Lake graben; the latter is filled by Cretaceous red beds and Tertiary detritus. East of the foliated leucogranite, early Paleozoic limestone and quartzite blocks with ultramylonitic fabric suggest that D3 ductile shearing also involved the host rocks. Because of their small size and poor outcrop conditions, these Paleozoic rocks are not represented in Figure 2. Meter- to decimeter-size blocks of Haihui porphyritic granodiorite enclosed into the foliated leucogranite exhibit the same mylonitic fabric with normal shearing like that in the leucogranite host rocks. These relative chronological relationships of the post-plutonic D3 deformation are in agreement with radiometric dates (see section 4).

\subsection{D2 Deformation}

The D2 deformation corresponds to the decakilometer-scale NE-SW anticline of the Lushan massif. This deformation is characterized by different structures depending on the lithology and geometric position in the rock succession. D2 upright folds with axial planar cleavage reworking earlier D1 structures are observed near the base of the Sinian sequence. Geometrically upward, in the Sinian and Paleozoic rocks, 

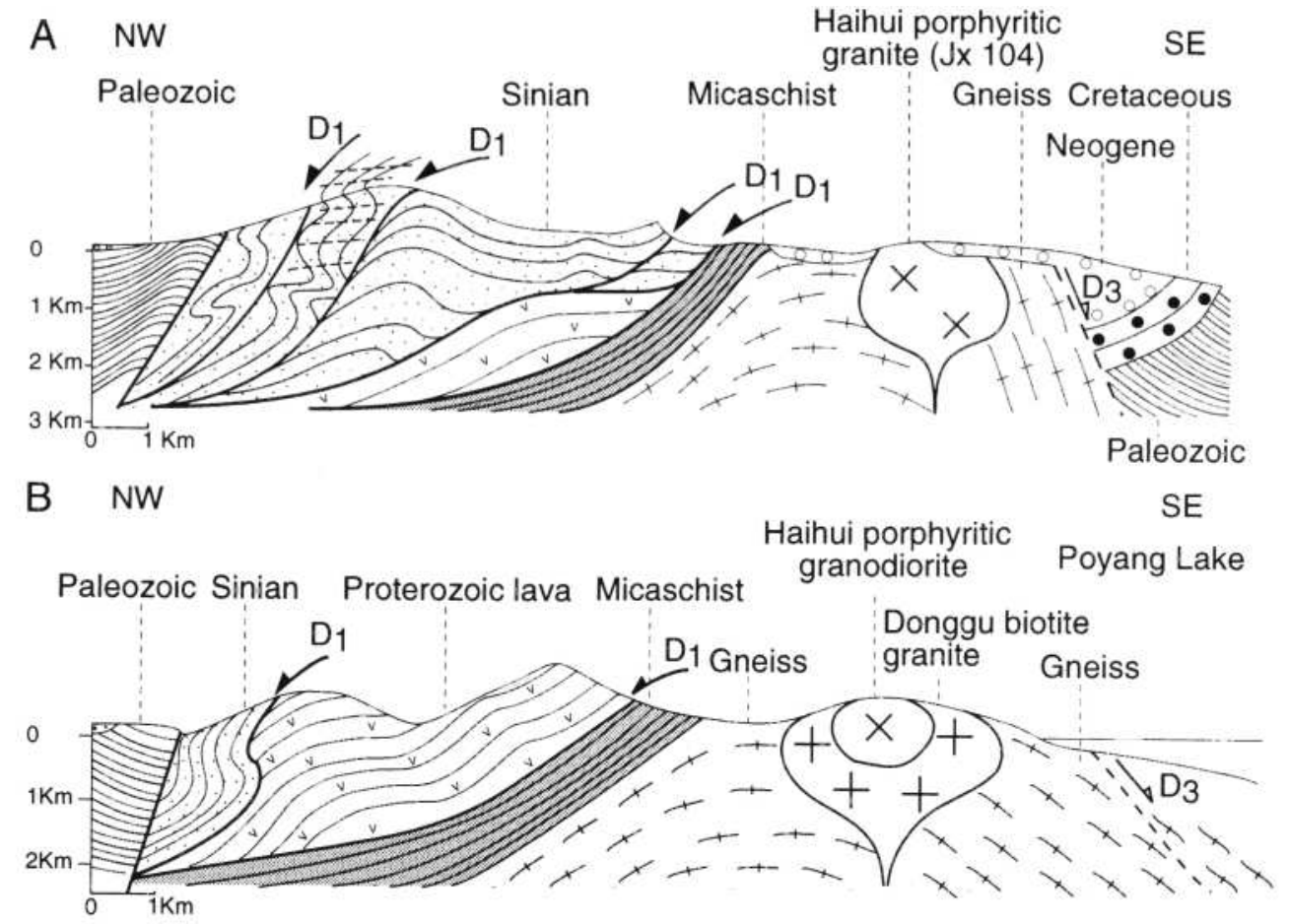

C SW

Hengtang Slate

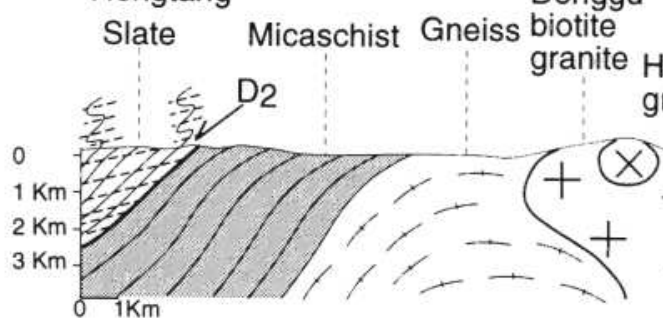

Foliated leucogranite
NE $\begin{array}{c:c}\text { Micaschist } & \text { Cretaceous } \\ \text { phyritic } & \text { Neogene }\end{array}$ granodiorite

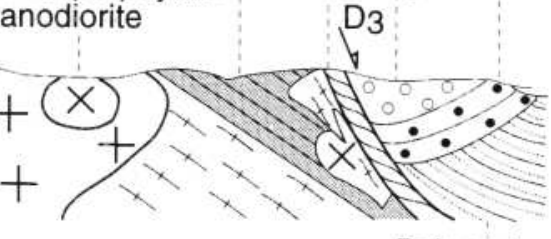

Paleozoic

Figure 3. Cross sections through the Lushan massif (location in Figure 2).

NE-SW folds are also recognized, but since they are overturned to the NW, they are attributed to D1 (see section 3.3).

At the SW margin of the Lushan massif a $30^{\circ}-40^{\circ} \mathrm{SW}$ dipping slaty cleavage (S2) occurs in the Proterozoic slate (Figure 6). Folding is seldom observed there, but beddingcleavage relationships show a southwestward overturning (Figures 3, and 4). The S2 cleavage bears a $\mathrm{N} 50^{\circ} \mathrm{E}$ trending mineral and stretching lineation. In section parallel to lineation and perpendicular to cleavage, top-to-the-SW shear criteria are observed. Symmetrically, at the NE end of the anticline, bedding and cleavage dip northeastward, both in the Paleozoic rocks and in the Sinian rocks. Paleozoic formations are poorly exposed, but brittle deformation accommodated by slip on the layers can be found in Cambrian limestones. In Sinian sandstone and conglomerate, bedding and cleavage angular relationships indicate a NE vergence. The cleavage plane bears a $30^{\circ} \mathrm{N}-\mathrm{N} 50^{\circ} \mathrm{E}$, NEdipping lineation marked by muscovite flakes and stretched quartz grains and pebbles. In quartz-rich sandstones, shear bands, asymmetrically recrystallized clasts, and sigmoidal muscovite indicate a top-to-the-NE shearing (Figure 7). Locally, east of Guankou in the Middle Proterozoic lavas, the NE-SW foliation dips southeastward and bears an unusual $N 10^{\circ} \mathrm{E}$ trending stretching lineation. In this area the foliation is overturned; thus, when rotated to the normal attitude, the lineation recovers a NE-SW trend. Consequently, kinematic indicators restored to their primary orientation indicate a topto-the-SW shearing (Figure 7).

The D2 deformation is also recognized in the metamorphic rocks underneath the lavas where both micaschists and gneisses exhibit a NE-SW mineral lineation defined by stretched pebbles, biotite streaks, amphibole needles, and elongated, recrystallized K-feldspar clasts (Figure 2). In spite of some annealing as shown texturally by quartz and feldspar, sharp extinction, straight grain boundaries, or $120^{\circ}$ triple junctions (Figures 7c-e), asymmetric fabrics can still be observed. The most widespread shear criteria consist of 


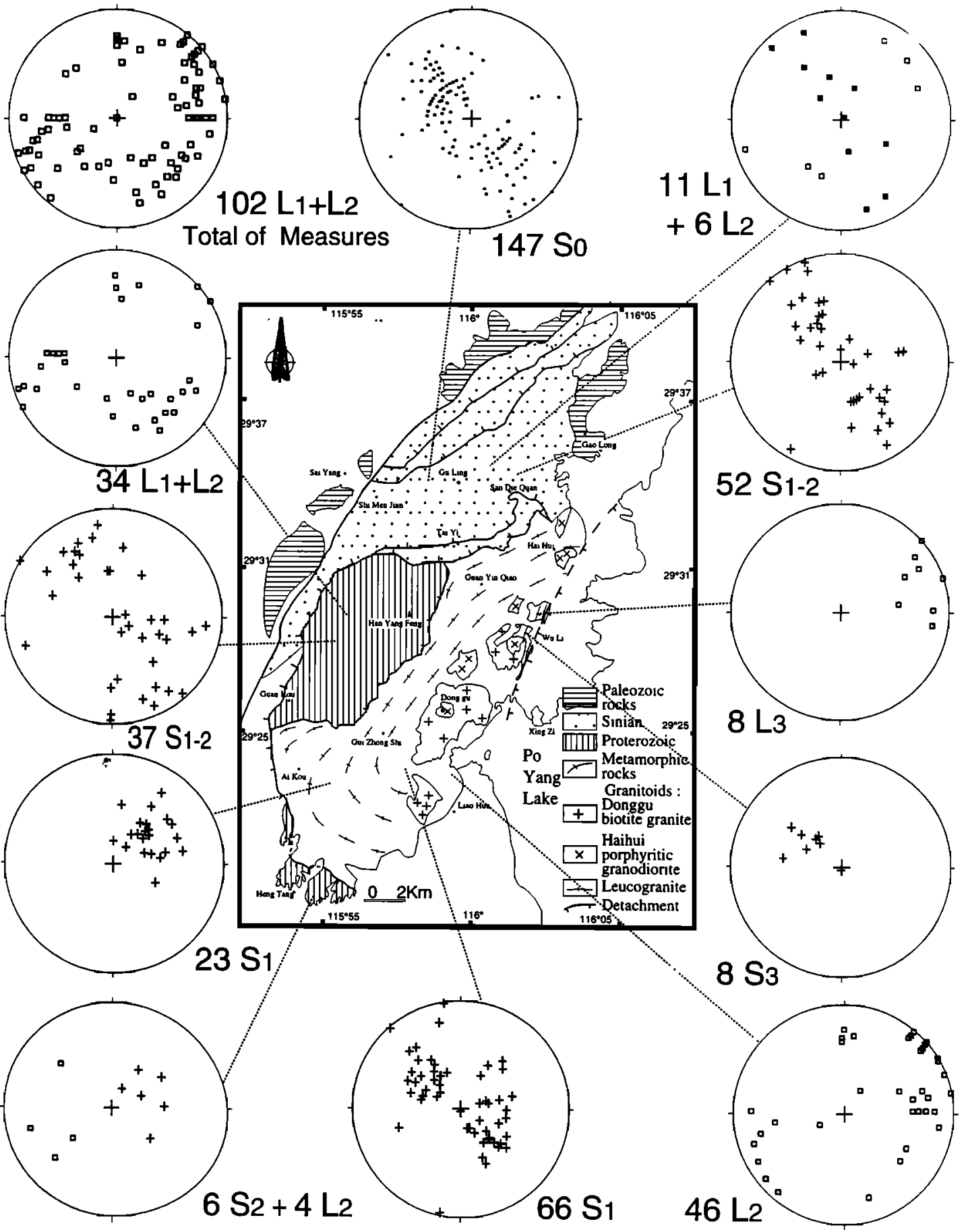

Figure 4. Structural analysis of the planar and linear elements in the Lushan massif (Schmidt net, lower hemisphere). S0 corresponds to the bedding plane in the Sinian sedimentary rocks; S3 and L3 refer to the shear plane and high-temperature slickenline, respectively, formed during the D3 event along the ductile normal fault bounding the Lushan massif to the east. S1-2 corresponds to the main regional foliation relevant to D1 and D2 deformations; L1 and L2 refer to stretching lineations attributed to D1 and D2 events, respectively.

asymmetric pressure shadows around garnet or quartz grains (Figure 7). Shear bands with curved amphibole and sigmoidal grains of K-feldspar or staurolite are also found (Figure 7). In the central part of the Lushan massif (i.e., south of Guanyin Qiao) the NE-SW mineral lineation is still clearly observed but the symmetry of the fabric indicates a coaxial flow (Figure 7). In the micaschists and gneisses, commonly developed biotite, garnet, and staurolite indicate an intermediate pressure-intermediate temperature type of metamorphism. However, it is worth noting that the above described shear 

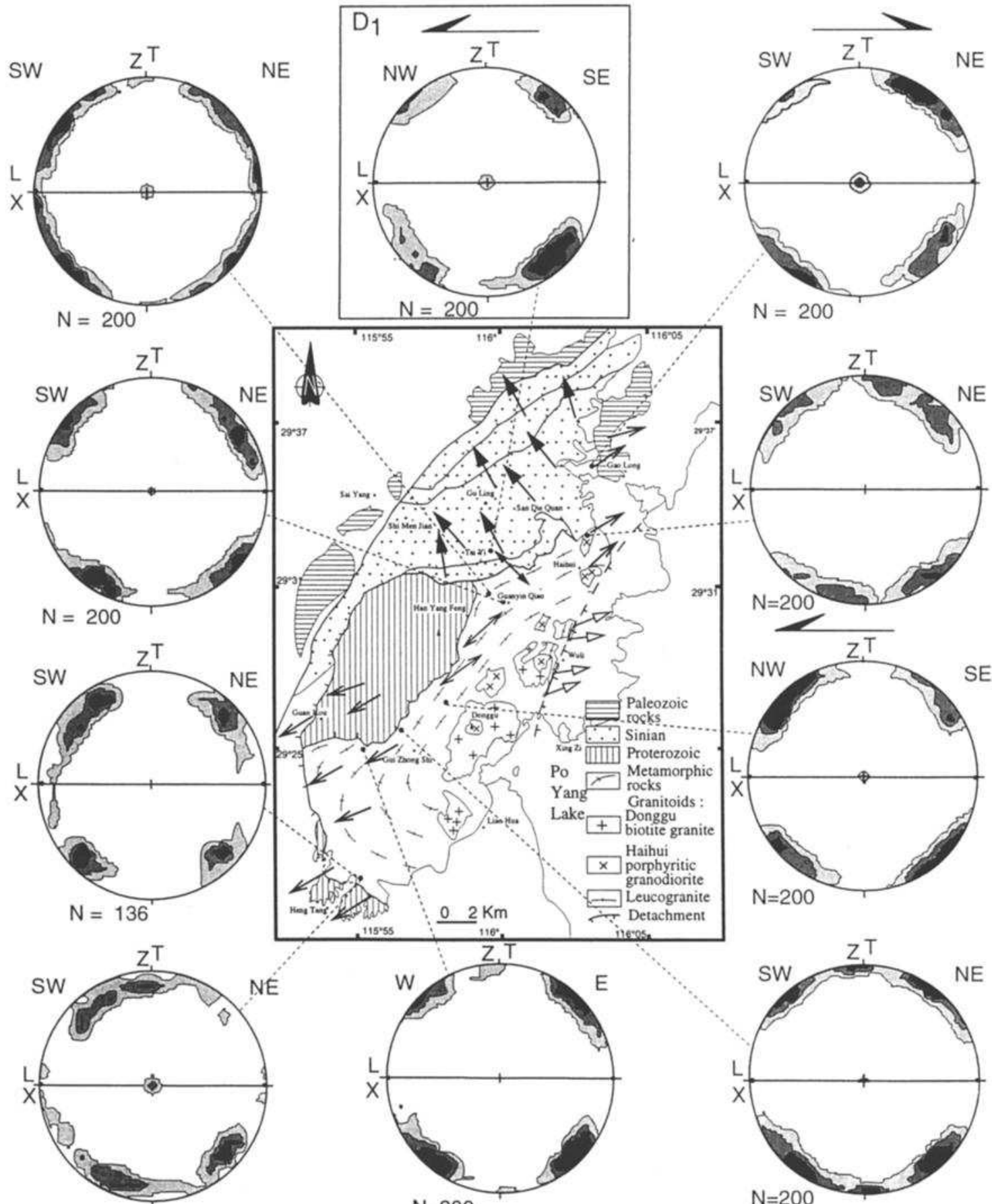

$$
\begin{aligned}
& \mathrm{N}=64 \\
& \mathrm{D}_{3} \text { ductile normal fault in leucogranite } \\
& \mathrm{D}_{2} \text { Sense of shear, mineral lineation } \\
& \mathrm{D}_{2} \text { coaxial flow }
\end{aligned}
$$

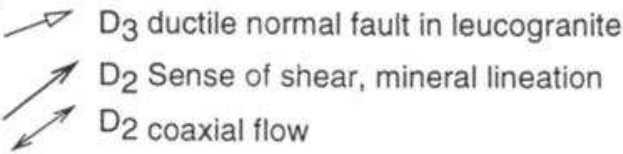

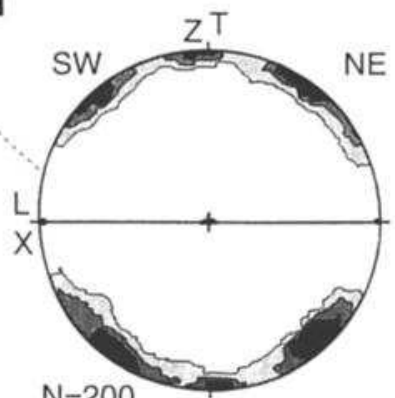

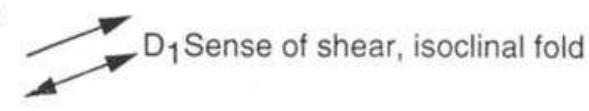

Figure 5. Kinematic map of the three deformation phases in the Lushan massif and quartz $c$ axis diagrams (Schmidt net, lower hemisphere). 


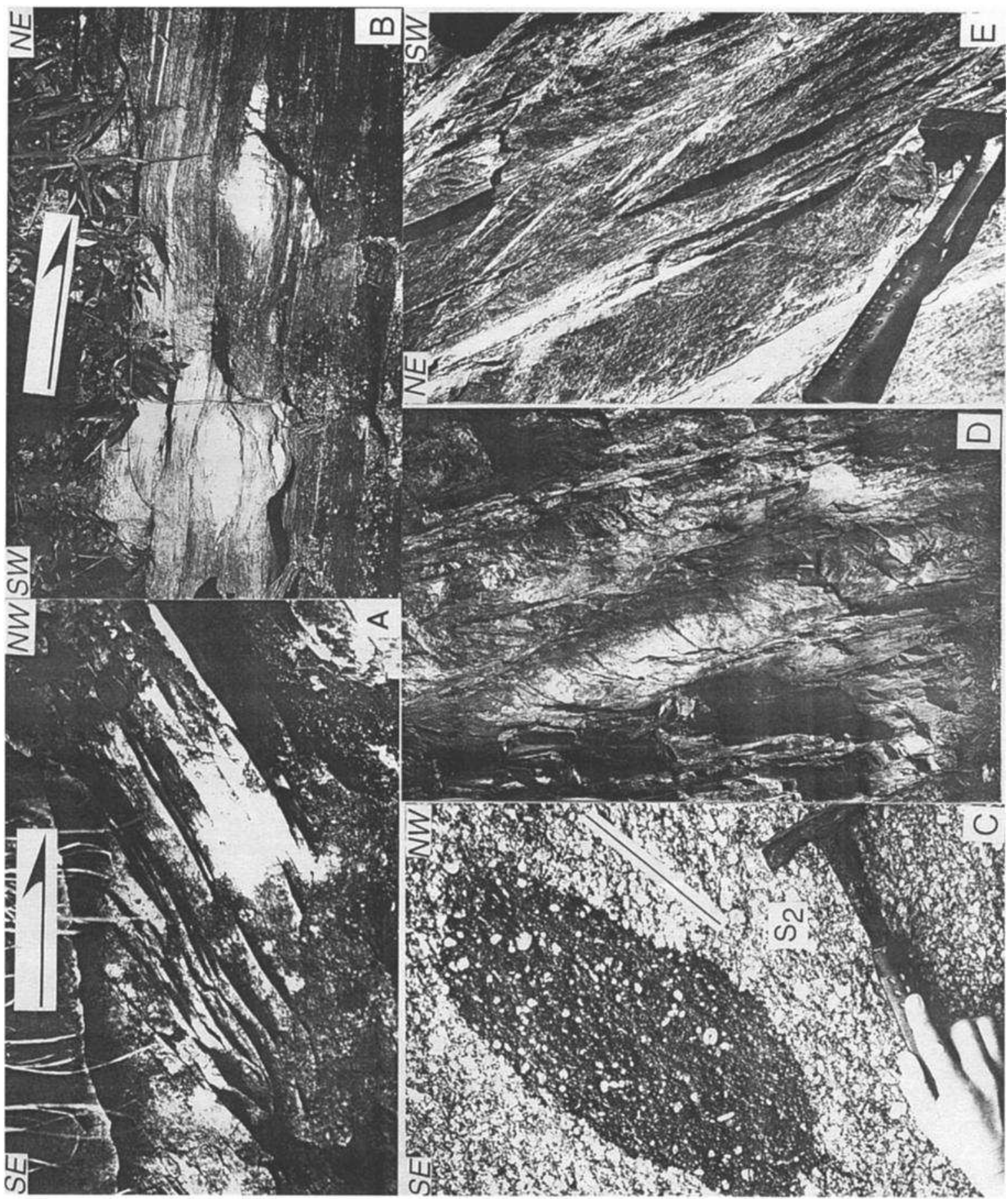

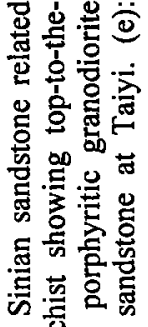

. 可的少

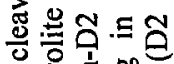

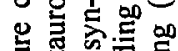

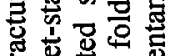

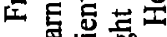

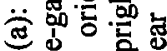
※.

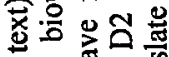
들 프응 을

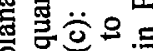
要要

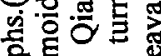
응

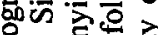

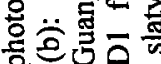

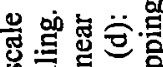
공 응

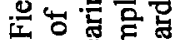

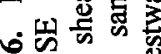

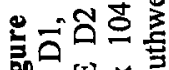

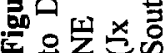




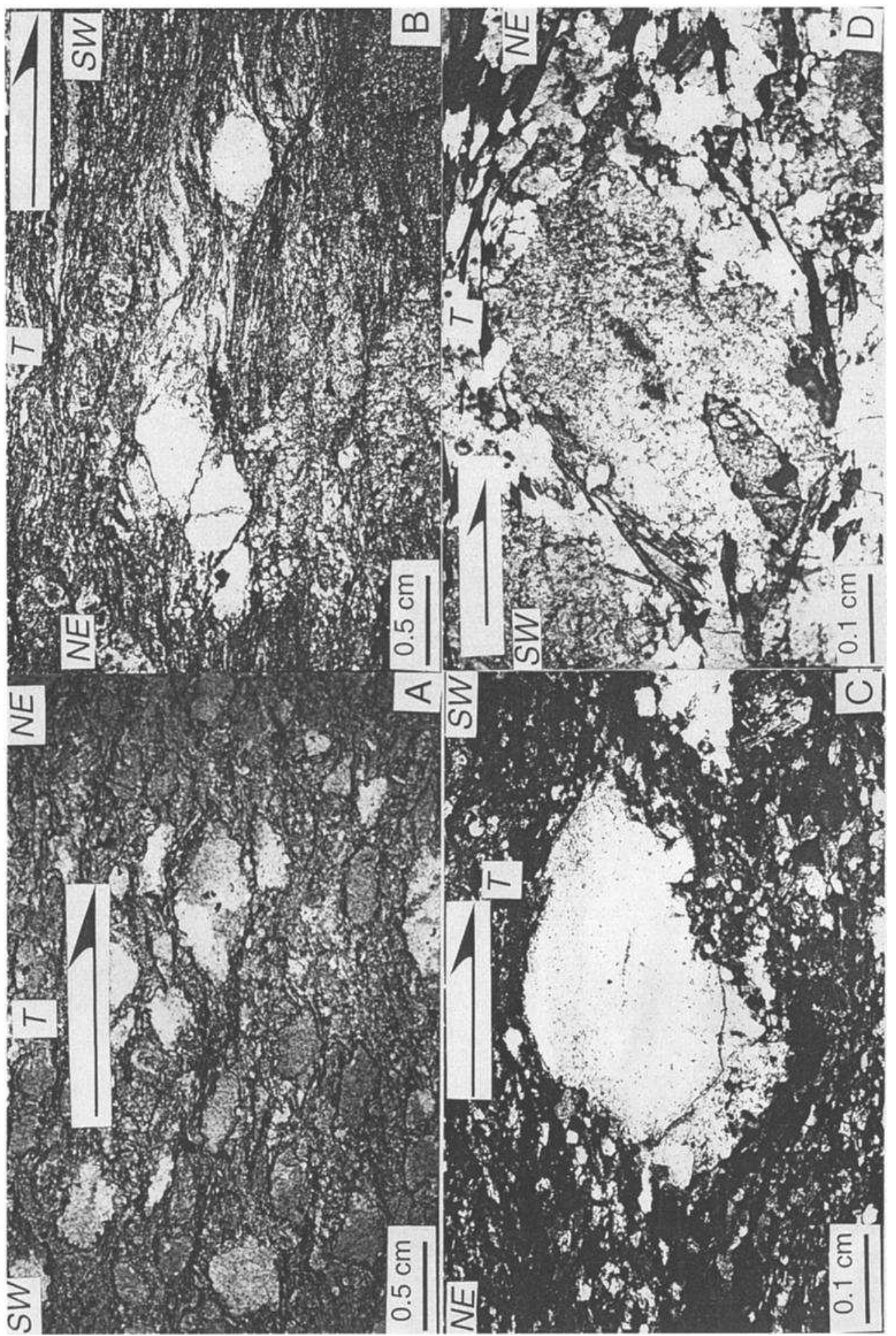

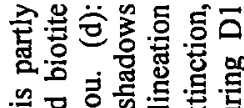

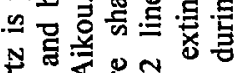

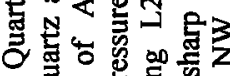

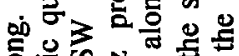
흥은 눈

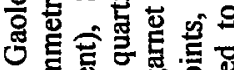

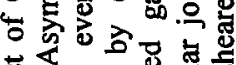

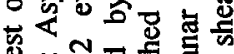

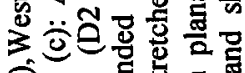

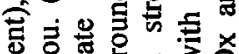

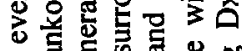

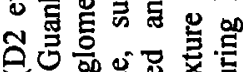

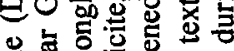

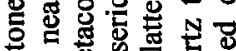

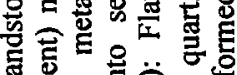

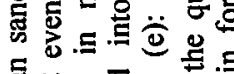

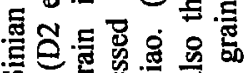
कि .플

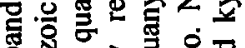

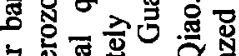
为哥

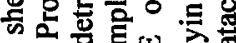

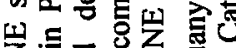

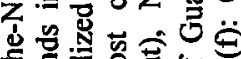

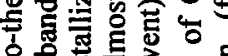

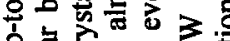

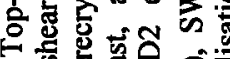

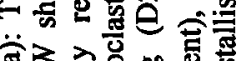

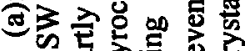

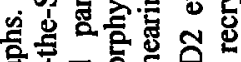

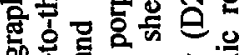

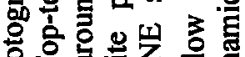

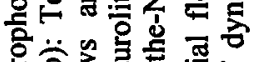

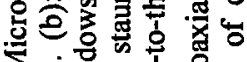

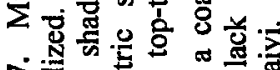
들 的

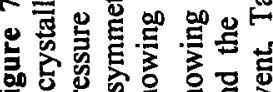

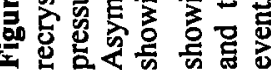




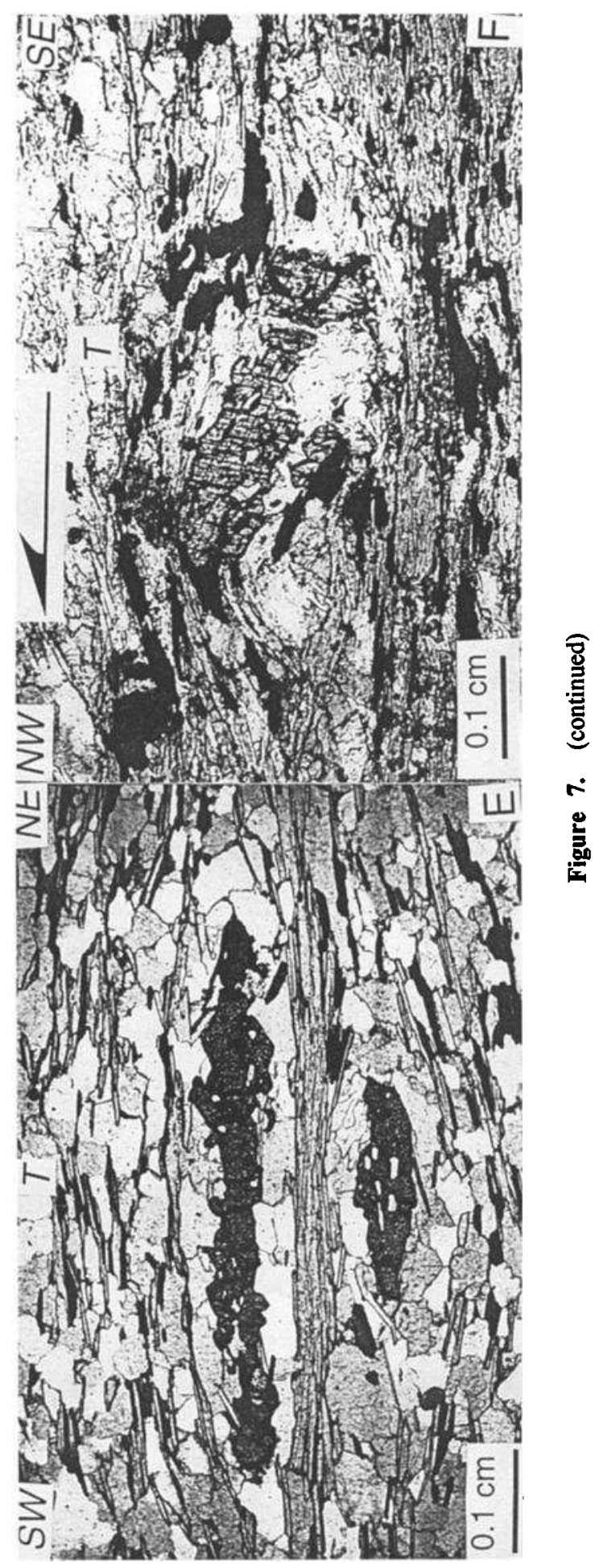


criteria overprint the metamorphic assemblages related to this older event. Therefore the deformation structures are not coeval with peak metamorphic conditions, but overprint the metamorphic assemblages. A convergent conclusion can be drawn from the study of quartz fabrics.

Quartz $c$ - axes have been measured using a universal stage. The corresponding subfabrics (Figure 5) exhibit some general characteristics. Namely, all the diagrams have an orthorhombic symmetry with two suborthogonal point maxima. In a few cases, one maximum is more populated than the other. The location of points along the diagram edge, between the stretching lineation ( $X$ axis) and the foliation pole ( $Z$ axis) indicates that basal $<a>$ gliding system is dominant. However, the few $c$ - axes plotting in the center of the diagram show that the prism $<a>$ system is also activated to accommodate plastic flow. In agreement with natural and experimental data [e. g., Etchecopar, 1977; Law, 1990, and references therein], such quartz fabrics develop under low- to middle-temperature conditions (i. e., $300^{\circ}-400^{\circ} \mathrm{C}$ ). We note that these conditions do not comply with the amphibolite facies metamorphism. Therefore these quartz $c$ - axis fabrics likely developed subsequent to the peak metamorphism experienced by the gneisses of the Lushan massif. This conclusion agrees with the crystallization-deformation timing since, as shown above, shear criteria develop upon metamorphic assemblages. The bulk kinematic picture provided by the quartz $c$ - axis fabrics corresponds to noncoaxial flow at the SW and NE ends of the Lushan anticline and coaxial flow between Guizon and Guanyin Qiao (Figures 2, and 5)

Moreover, the metamorphic rocks exhibit abundant evidence of a ductile, post-metamorphic deformation. Centimeter- to decimeter-scale, frequently striated quartz veins, concordant to the foliation of the gneisses and micaschists, suggest a reworking of this surface as a shear plane. The asymmetric shape of the quartz veins allows us to infer a sense of shear (Figure 6), with top-to-the-NE and SW shearing at the $\mathrm{NE}$ and $\mathrm{SW}$ terminations of the Lushan anticline, respectively. In the central part of the massif, between Guizhong and Guanyin Qiao, symmetric veins predominate and attest to coaxial flow. This kinematic pattern is consistent with other shear criteria observed in the metamorphic rocks.

The D2 deformation is also observed in the Haihui porphyritic granodiorite. Planar and linear fabrics are well defined by mafic microgranular enclaves and by biotite and $\mathrm{K}$ feldspar preferred orientation (Figure 6). The Haihui granodiorite exhibits a $\mathrm{N} 50^{\circ} \mathrm{E}$ trending mineral lineation parallel to that observed in metamorphic rocks. Under the microscope the granodiorite fabric is characterized by subsolidus fabrics such as zoned plagioclase with syneusis texture, myrmekite in K-feldspar, cracked titanite, and other resistant minerals. In contrast, quartz does not exhibit plastic deformation structures [Hibbard, 1987; Faure et al., 1996]. The accordance of planar and linear structures of the Haihui granodiorite with those related to the D2 deformation in the host rocks shows that this pluton is syntectonic with respect to D2. Its Early Cretaceous titanite U/Pb age (see section 4.3) provides a strong constraint on the timing of the deformation history.
The lower part of the Sinian sandstones and the metamorphic rocks are cut by numerous aplite and pegmatite dikes. Most of these dikes are also deformed. The dikes at high angle to the foliation are buckled with subhorizontal axial planes, and those dikes at low angle to the foliation are boudinaged and stretched in the NE-SW direction. This geometric pattern allows us to define roughly the principal strain axes, characterized by NE-SW stretching ( $X$ axis) and vertical shortening ( $Z$ axis). Since the intermediate $Y$ axis is perpendicular to the Lushan anticline axis, it has to be a
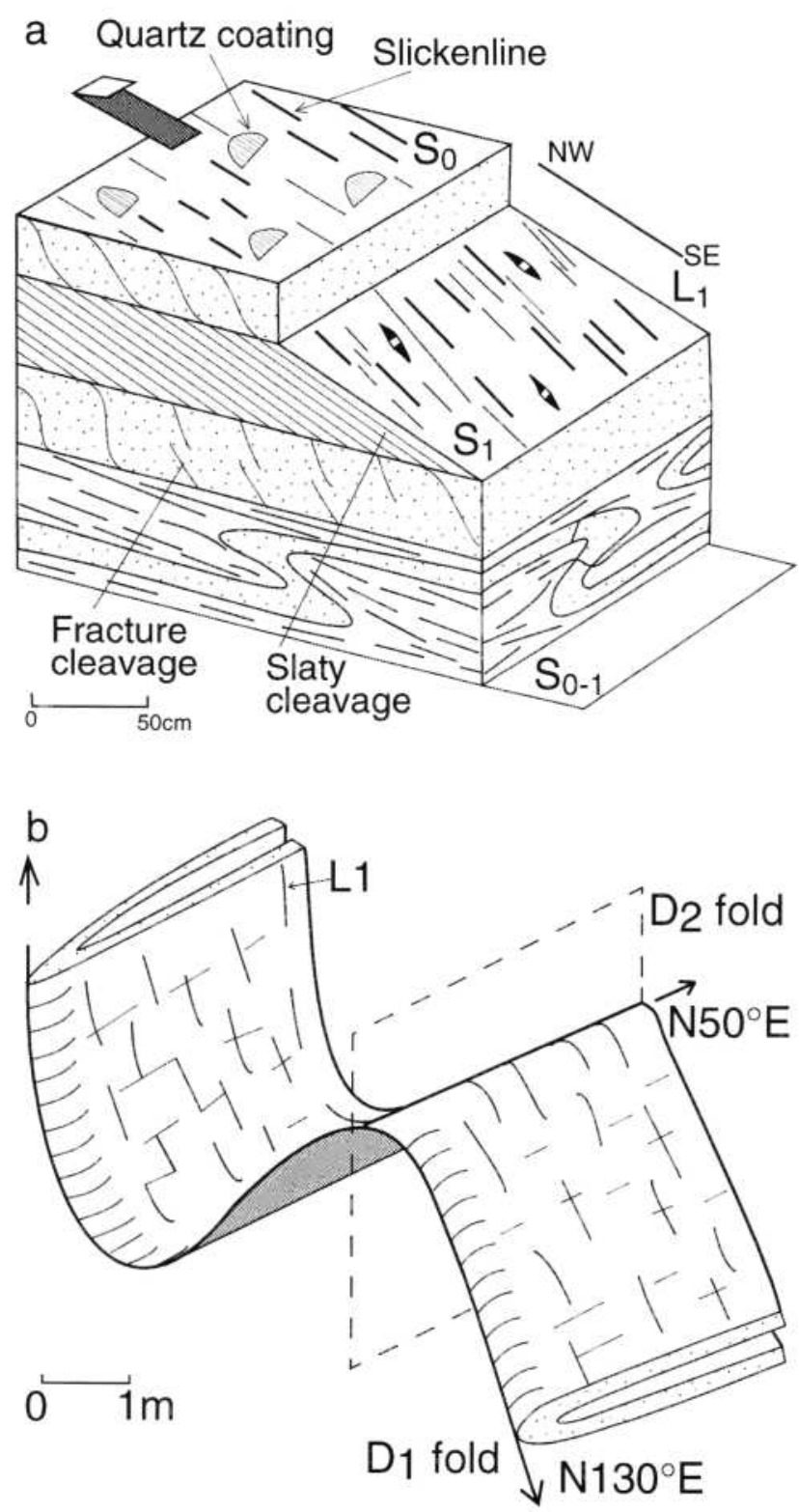

Figure 8. (a) Schematic block diagram of D1 phase structures with cleavage refraction in sandstone beds, stretching lineation (L1), slaty cleavage (S1), and slickensides and quartz coating on bedding ( $\mathrm{S} 0$ ). When shearing is high, isoclinal fold develops and bedding and cleavage become parallel (S0-1). (b) Sketch showing DI NW-SE trending isoclinal, fold parallel to $\mathrm{L} 1$, refolded by $\mathrm{D} 2 \mathrm{NE}-\mathrm{SW}$ trending upright fold. 
shortening axis too, but the lack of strongly folded dikes with vertical axial planes shows that the amount of shortening in the NW-SE direction (along $Y$ ) was less than in the vertical direction (along $Z$ ). The low-angle cleavage plane in slates and subhorizontal folding of dikes also argue for a vertical shortening during D2 deformation. The divergent senses of shear, top-to-the-SW and NE at the SW and NE ends of the Lushan massif, respectively, are interpreted as edge accommodation around the anticline periclinal terminations.

\subsection{D1 Deformation}

Prior to D2 folding and coeval magmatism, the Lushan massif experienced an older tectonic event (D1), well recorded in the Sinian series. Along a NW-SE transect the intensity of D1 increases from Paleozoic to Sinian, that is to say, from top to bottom of this tectonostratigraphic unit. Maximum deformation is located along the tectonic boundary between the Sinian and Proterozoic formations where D1 is characterized by a metamorphic foliation subparallel to bedding (SO-1) except in the hinges of isoclinal folds (Figure 8). S0-1 bears a $120^{\circ} \mathrm{N}-150^{\circ} \mathrm{E}$ trending mineral and stretching lineation parallel to isoclinal fold axes (Figures 4, 6). D1 structures are folded by upright $\mathrm{N} 50^{\circ} \mathrm{E}$ trending $\mathrm{D} 2$ folds (Figures 6, and 8). Upward in the Sinian sequence, metamorphism progressively disappears, and bedding is deformed by fracture or slaty cleavage (S1) depending on the lithology (Figures 6 and, 8). Near the boundary between Sinian and Paleozoic series, hectometer-scale recumbent folds can be observed (e. g., at Shimen Jian, Figures 2 and, 3). S1 bears a NW-SE (N120 E-150 E, Figure 4) stretching lineation, and on the bedding surface (S0), slickenlines and quartz-fiber coating indicate a top-to-the-NW displacement accommodated by slip on the layers. Near Guling (Figure 2), fold axes trending NE-SW with axial planes overturned to the $\mathrm{NW}$ also belong to $\mathrm{D} 1$ deformation. From the kinematic point of view, top-to-the-NW shearing observed in the field is confirmed by microscope-scale shear criteria such as pressure shadows, shear bands, or oblique quartz shape fabrics. Near the Sinian-Proterozoic boundary, for instance at Taiyi, quartzmuscovite assemblages develop in the pelitic rocks. Kyanite grains, always deformed, cracked, and often surrounded by pressure shadows, are also observed (Figure 7). This kyanite appears as a pre-D1 mineral cataclazed during D1.

At the base of the Sinian series, where D1 is the most intense, quartz $c$ - axis fabric shows the development of a point maximum oblique to the foliation pole ( $Z$ axis) in agreement with a top-to-the-NW shearing (Figure 5 ). The existence of a weak secondary maximum around the $Y$ axis (in the center of the diagram) indicates dominant activation of basal $\langle a\rangle$ with a minor component of prism $<a>$ gliding systems. In terms of deformation conditions, such quartz $c$ - axis fabrics develop under low temperatures $\left(300^{\circ}-400^{\circ} \mathrm{C}\right)$ which are not compatible with the intermediate temperature-intermediate pressure metamorphism of the Lushan massif and kyanite occurrence in the same thin section. This quartz $c$ - axis result also supports the conclusion that kyanite crystallization predates Dl shearing. The close geometric association between kyanite-bearing metapelites and underlying biotitegarnet-staurolite micaschists suggests that both assemblages belong to the same metamorphic event, which we designate as
Dx in the following discussion. Therefore the three ductile deformation events documented in the Lushan massif are younger than Dx. D1 appears to be restricted to the rocks located at the Proterozoic-Sinian boundary. The tectonic significance of each event is best constrained in context of our new radiometric dates.

\section{Geochronological Data}

\section{1. ${ }^{40} \mathrm{Ar} /{ }^{39} \mathrm{Ar}$ Geochronology}

A large set of samples representative of the different tectonometamorphic units in the Lushan massif has been collected for ${ }^{40} \mathrm{Ar} /{ }^{39} \mathrm{Ar}$ age determinations. About 20 samples from the Proterozoic basement rocks, the metamorphic base of the overlying Sinian cover, and the granitoids have been selected and analyzed using furnace step-heating of bulk separates and laser probe dating of single grains. The detailed results of this geochronological study will be published in a forthcoming paper (W. Lin et al., manuscript in preparation, 2000), but a brief summary of this work is given here to provide new constraints on the thermal and tectonic evolution of the Lushan massif. The new data are presented in Figure 9 and Table 1. Figures 10 and 11 are representative examples of ${ }^{40} \mathrm{Ar} /{ }^{39} \mathrm{Ar}$ age spectra and laser probe ablation maps. Details of the different analytical procedures are given in the appendix.

4.1.1. Proterozoic basement: Gneisses and micaschists were sampled mainly in the southern part of the dome, and bulk separates and single grains of amphibole, muscovite, and biotite were investigated. Among these minerals, two populations of amphiboles from amphibolitic gneisses (Jx24 and $\mathrm{J} \times 28$ ) give the oldest isochron dates of $140.5 \pm 2.9$ and $133.1 \pm 1.4 \mathrm{Ma}$, respectively $(2 \sigma$ Standard Error of the weighted mean). Their $\mathrm{Ca} / \mathrm{K}$ ratios differ markedly by a factor of 6 , and both display younger ages in the first gas increments, probably related to the presence of micaceous inclusions which can be observed in thin section and which are abundant in the case of sample Jx24. This latter sample displays a discordant age pattern that could be indicative of the presence of excess argon. Muscovite Jx60 from a garnetstaurolite micaschist has been analyzed by laser step-heating and spot ablation of single grains. The single-grain age spectrum is partly discordant, recording a concave shape in the central part of the release pattern (Figure 10). The total gas age of $123.5 \pm 1.1 \mathrm{Ma}$ is slightly younger than the age of $125.6 \pm 1.2 \mathrm{Ma}$ calculated over the less discordant portion of the spectrum, representing $45 \%$ of the gas released (Figure 10). A series of nine laser ablations performed perpendicular to the surface of a second grain from this sample (Figure 11a) suggests that the minimum of the saddle in the spectrum can be correlated with minimum ages of 115-117 Ma obtained on the rim of the mica, whereas the core retains consistent ages corresponding to a mean value of $125.2 \pm 0.7 \mathrm{Ma}$. A younger age of $99.6 \pm 1.0 \mathrm{Ma}$ is recorded by a muscovite population from a quartzite at Wuli (sample Jx5), in the vicinity of the ductile normal fault contact with the overlying Proterozoic and Paleozoic formations. Five biotite concentrates have been analyzed in this SW part of the metamorphic dome. The age spectra of these biotites frequently display minor 


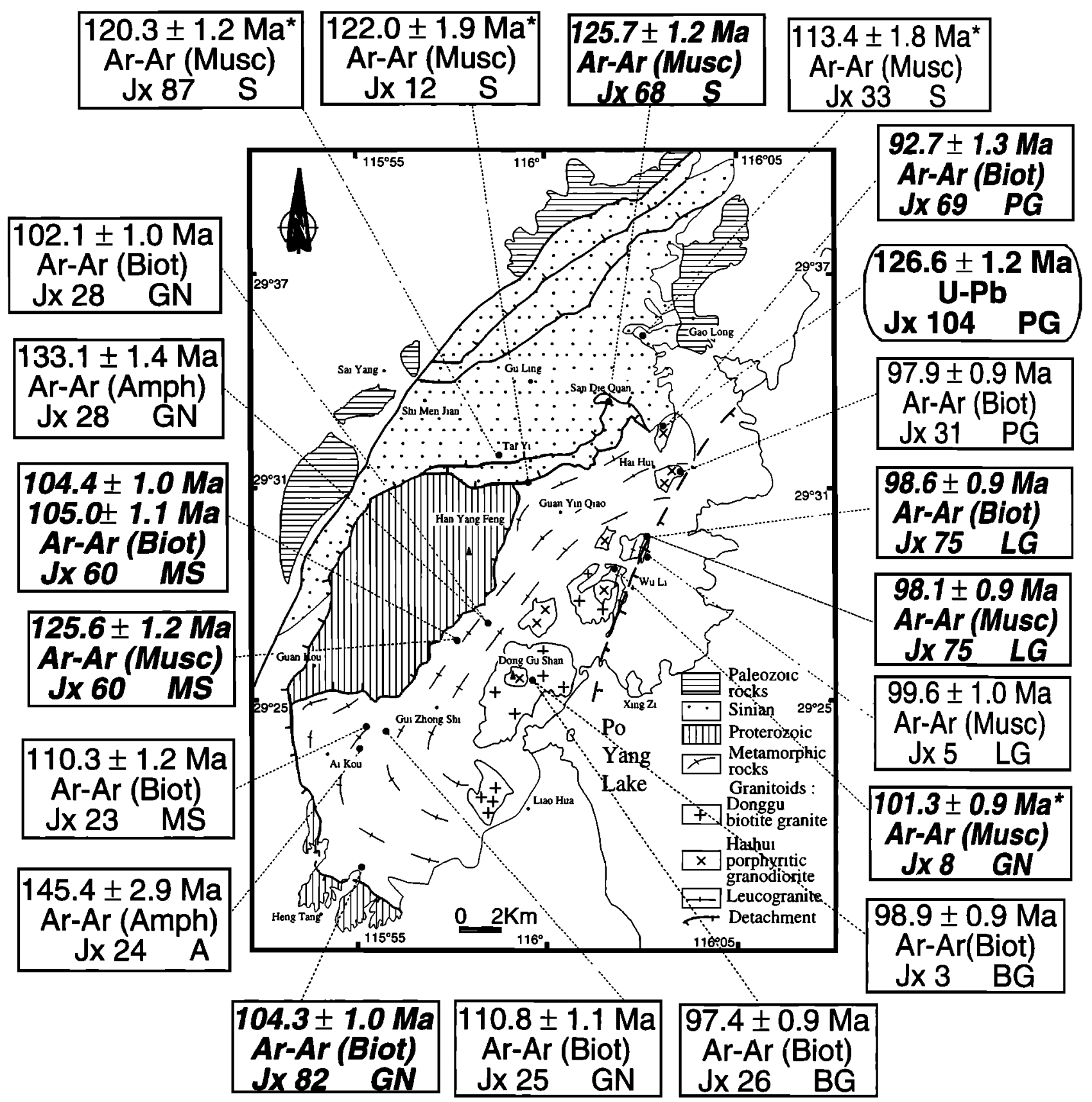

Figure 9. Structural map of the Lushan massif showing the available radiometric data. For ${ }^{40} \mathrm{Ar} /{ }^{39} \mathrm{Ar}$ dates, straight and italic bold letters correspond to population (resistance furnace) and single-grain laser analyses, respectively. Asterisks indicate mixed ages. Musc, biot, and amph stand for muscovite, biotite and amphibole respectively, and BG, LG, PG, S, MS, A, and GN indicate the lithology biotite granite, leucogranite, porphyritic granite, Sinian sandstone, micaschist, amphibolite, and gneiss, respectively. For U-Pb date (sample $\mathrm{J}_{\mathbf{X}}$ 104), concordia diagram is given in Figure 12.

disturbances related to the presence of chlorite impurities in the bulk mineral separates (Figure 10). These biotites give dates ranging from $102.1 \pm 1.0 \mathrm{Ma}$ for a biotite-amphibole gneiss (sample Jx28, Figure 9) to $110.8 \pm 1.1 \mathrm{Ma}$ for a twomica gneiss collected farther to the SW (sample Jx25). To the south, an age of $104.3 \pm 1.0 \mathrm{Ma}$ is reported for a mylonitic metaconglomerate (sample Jx82) in the contact zone with the overlying weakly metamorphosed Proterozoic slates (Figure 10).

4.1.2. Granitoids: Different types of granitoids showing variable structural relationships with their country rocks were collected mainly in the northeastern and central parts of the Lushan dome. Samples $J \times 3$ and Jx26 are from the central posttectonic Donggu pluton and give consistent biotite 


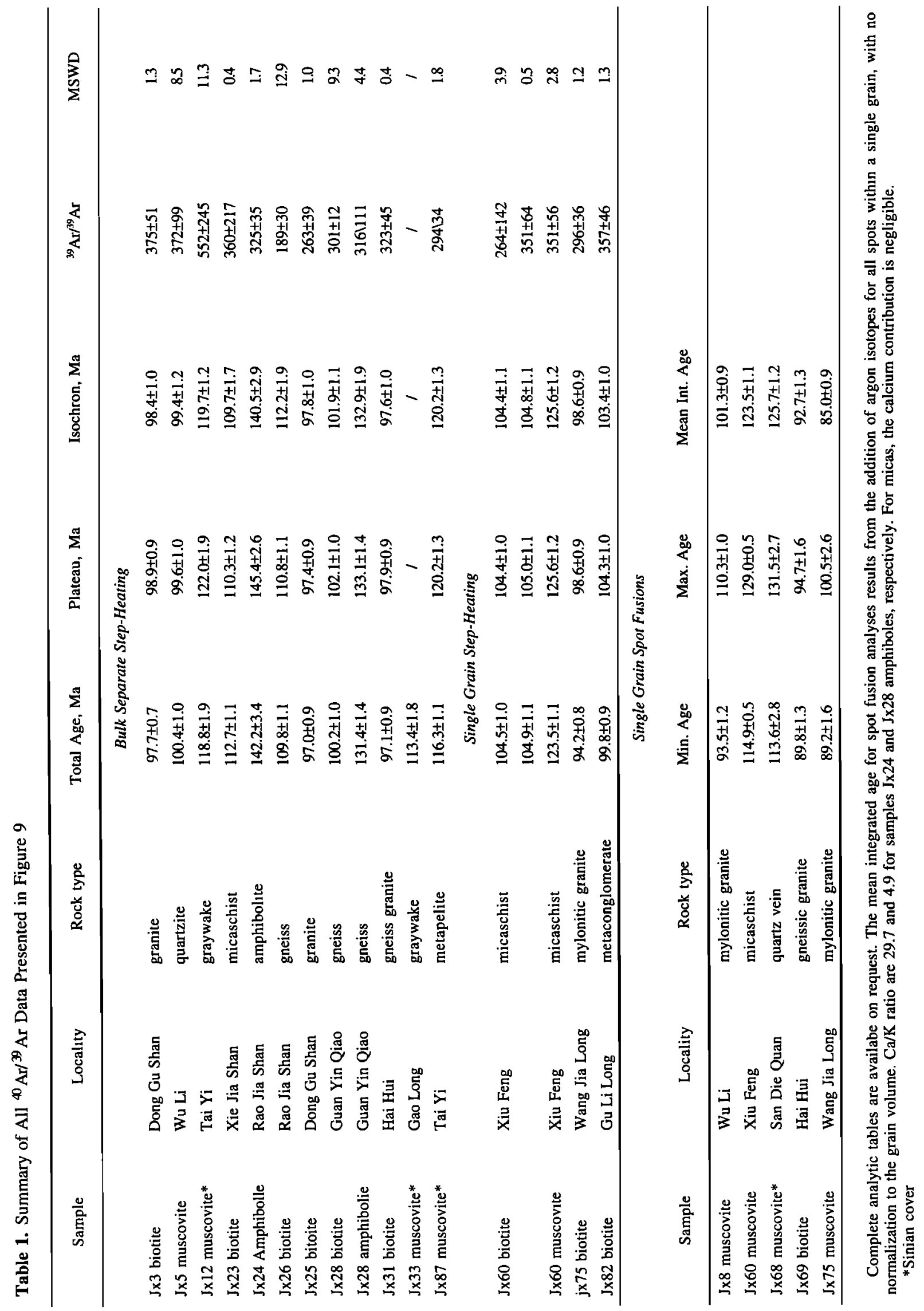



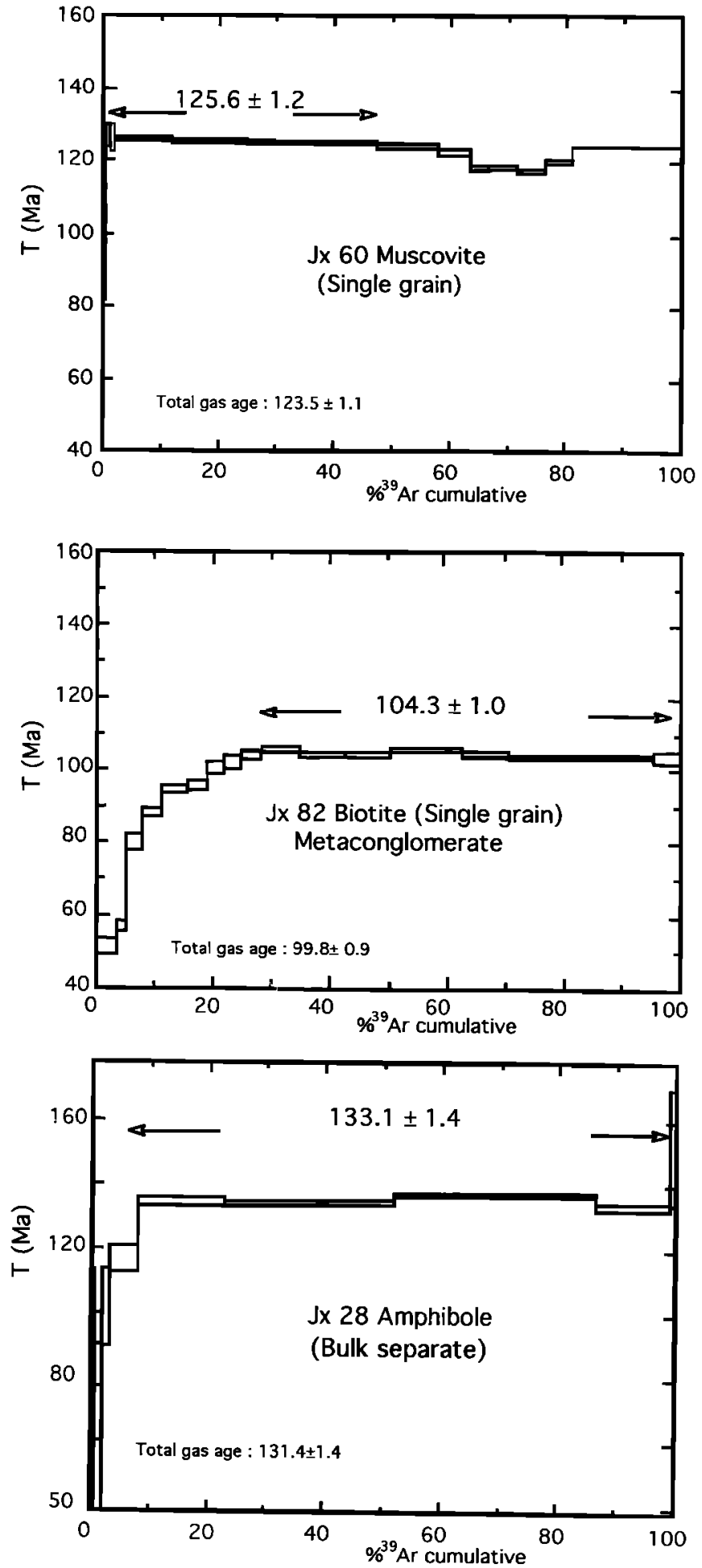

Figure 10. Three examples of ${ }^{40} \mathrm{Ar} /{ }^{39} \mathrm{Ar}$ age spectra (see location in Figure 9) on muscovite, biotite and amphibole.

cooling ages close to $98 \pm 1 \mathrm{Ma}$. Two biotites from the Haihui gneissic granodiorite give ages of 93-98 $\mathrm{Ma}$ that fall broadly within the same age range (Jx31, and Jx 69).

Laser probe dating has been applied to two strongly sheared leucogranites near Wuli (Jx8, and $\mathrm{Jx} 75$ ). A series of laser pits in a muscovite from the first sample yields a zonation of apparent ages from $94 \mathrm{Ma}$ on the rim to $110 \mathrm{Ma}$ in the core of the mica. With muscovite $\mathrm{Jx} 75$ this zonation is less well developed with a minimum rim age of $89 \mathrm{Ma}$ and a core age of $100 \mathrm{Ma}$. Step-heating of a single biotite grain from this latter sample yields a plateau date of $98.6 \pm 0.9 \mathrm{Ma}$, consistent with the muscovite date.

4.1.3. Sinian: Four samples were taken at the base of the Sinian sandstone-pelite cover where metamorphic assemblages including kyanite and white mica were found during the field survey. Three bulk separates of muscovite (samples $\mathrm{J} \times 12, \mathrm{~J} \times 33$, and $\mathrm{Jx} 87$ ) display similar, discordant age spectra showing a progressive increase of apparent ages from about 100 to $120-125 \mathrm{Ma}$ during incremental heating. These gradients are interpreted to result from the coexistence of two generations of muscovite in the studied samples as observed in thin section. Laser probe dating was applied to a single muscovite from a quartz vein inside a shear zone with top-tothe-ENE kinematic indicators related to the D2 event (San Die Quan waterfalls), $1 \mathrm{~km}$ structurally above the main contact between the Sinian series and the underlying basement. The ${ }^{40} \mathrm{Ar} /{ }^{39} \mathrm{Ar}$ spot fusion data from this muscovite (sample Jx68) do not reveal any significant age difference between core and rim (Figure 11b), corresponding to a mean integrated date of $125.7 \pm 1.2 \mathrm{Ma}$.

\subsection{Interpretation of ${ }^{40} \mathrm{Ar} /{ }^{39} \mathrm{Ar}$ Ages}

By contrast with the geochronology reported farther south in the Wugongshan massif [Faure et al., 1996], the first observation resulting from these new ${ }^{40} \mathrm{Ar} /{ }^{39} \mathrm{Ar}$ age

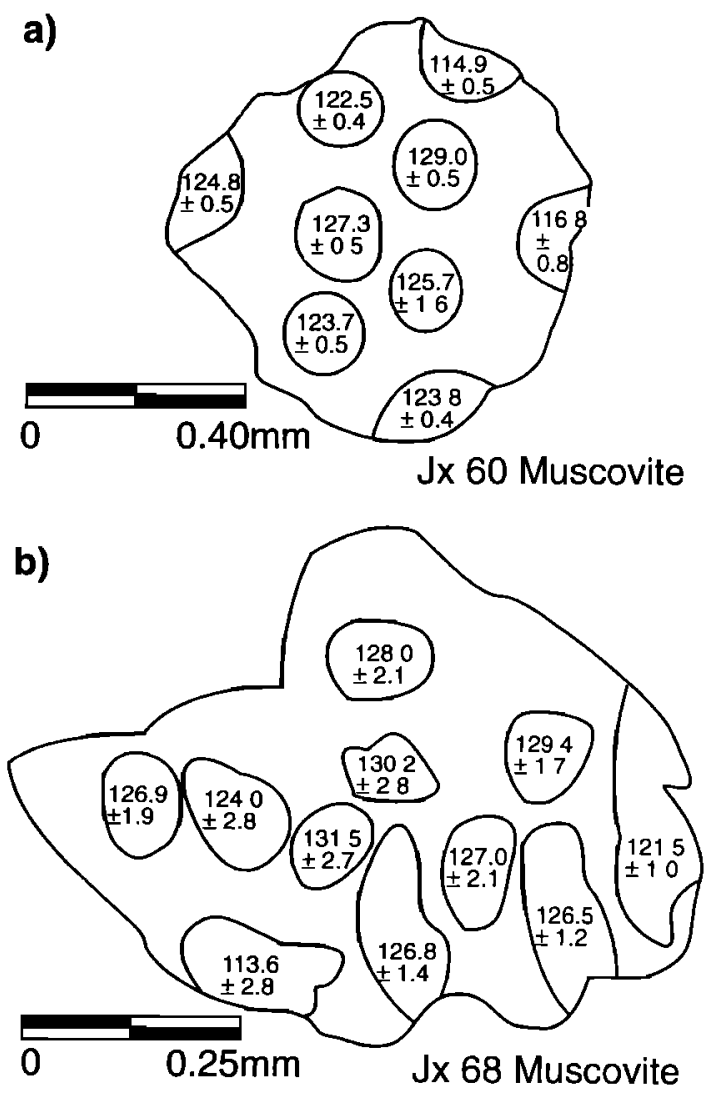

Figure 11. (a, b) Examples of laser spot analyses in muscovite (see location in Figure 9). 
determinations in the Lushan massif is that all fall in a range from about 140 to $100 \mathrm{Ma}$, thus pointing to the existence of a major cooling event in the Cretaceous, independently of the lithology or tectonostratigraphic level investigated. This is particularly noticeable for the schists of the Sinian metamorphic cover that have experienced lower thermal conditions than the underlying basement rocks and which partially preserve the earlier Dx metamorphic assemblages. However, there is no preserved record in these schists of ages older than the Cretaceous.

However, while a range of ages exists thoughout the different units, the ages form a consistent pattern within rocks of the same unit with older to younger dates for amphibole through muscovite then biotite. This pattern conforms to a generally accepted decrease in closure temperature for these minerals. According to Harrison [1981] and Dahl [1996], it is likely that amphibole ages of 140-133 $\mathrm{Ma}$ in the Proterozoic basement record the time when the metamorphic rocks passed through an isotherm between $500^{\circ}$ and $600^{\circ} \mathrm{C}$. Peak metamorphic conditions in the gamet-biotite-staurolite gneisses were attained before the Cretaceous, but no geochronological data are available to pinpoint precisely the delay before the time of closure of the amphiboles to argon diffusion represented by our data. Muscovite ages close to $125 \mathrm{Ma}$ in metamorphic rocks are interpreted to record cooling about $10 \mathrm{My}$ after amphibole. Recent experimental and field calibrations [Kirschner et al., 1996; Hames and Cheney, 1997] indicate that this cooling occurs at a temperature slightly above $400^{\circ} \mathrm{C}$. According to the new U$\mathrm{Pb}$ titanite ages given in section 4.3 , this cooling appears to be contemporaneous with the emplacement of a first generation of granitoids in the Lushan dome. Younger ages between 90 and $110 \mathrm{Ma}$ are recorded by muscovite from sheared leucogranites, suggesting that some argon loss occurred during shearing. Biotite ages range from 93 to 111 Ma throughout the massif, recording cooling at a temperature of $300^{\circ}-350^{\circ} \mathrm{C}$ [Harrison et al., 1985; Onstott et al., 1989]. Biotite ages are systematically older in the dated metamorphic rocks (102-111 Ma) than in the various granitoids (93-99 $\mathrm{Ma}$ ), suggesting some diachronous cooling history between these lithologies. However, all biotites became closed to argon diffusion after the emplacement of the granites. The combination of these new ${ }^{40} \mathrm{Ar} /{ }^{39} \mathrm{Ar}$ thermochronological data points to a mean cooling rate close to $5^{\circ}-10^{\circ} \mathrm{C} / \mathrm{My}$ for the period between 140 and $100 \mathrm{Ma}$. Anomalies exist to this general pattern that may be attributed to argon loss related to the thermal effect of the plutons or the shear zone activity.

\subsection{U-Pb Dating of the Haihui Granodiorite}

A series of five size fractions of titanite was dated by the $U$ $\mathrm{Pb}$ method to constrain the age of magmatism that led to the emplacement of the Haihui granodiorite. We elected to analyze titanite because inherited components from crustal sources are less frequent in this mineral than in cogenetic zircon in which we observed old cores by optical microscopy. Relative chronology estimated through intrusive relationships places the Haihui granodiorite between the older metamorphic rocks and the younger Donggu granite. The porphyritic granodiorite (Figure 3) truncates the country gneiss. Field observations through the pluton and adjacent rocks reveal the occurrence of megaxenoliths of the Haihui granodiorite within both the Donggu granite and the foliated leucogranite. Sample Jx104 is a porphyritic, medium-grained rock consisting of $60 \%$ felsic minerals (plagioclase, less $\mathrm{K}$ feldspar, and little quartz) and $40 \%$ mafic components (biotite and minor brown amphibole). The sample is characterized by a syn-D2 gneissic structure caused by preferred orientation of biotite and feldspar crystals. This structure reflects strain during crystallization of the magma, with the primary magmatic mineralogy being entirely preserved; no evidence for later subsolidus deformation can be recognized.

$\mathrm{U}-\mathrm{Pb}$ analytical data for magmatic titanite are given in Table 2, and the corresponding concordia diagram is shown in Figure 12. The fractions measured represent between 2 and 20 grains, selected individually under the binocular microscope to avoid any inclusions and cracked or translucent grains. The euhedral transparent titanites used are homogeneously pleochroic, with colors ranging from yellow and pale-brown. The five analyses yield identically concordant ages defining a mean value of $126.6 \pm 1.2 \mathrm{Ma}(2 \sigma$ Standard Error of the weighted mean) for titanite crystallization in the magma. Since titanite has blocking temperatures in excess of $700^{\circ} \mathrm{C}$ for the U-Pb chronometer [e.g., Zhang and Schärer, 1996; Corfu, 1996], this age can be interpreted to correspond to the time of magma crystallization within the host gneisses, dating emplacement of the Haihui granodiorite.

This age is significantly older than the ${ }^{40} \mathrm{Ar} /{ }^{39} \mathrm{Ar}$ ages from the same intrusion (Figure 9), giving a plateau at $92.7 \pm 1.3$ Ma on biotite (Jx31). This $30 \mathrm{Myr}$ age difference reflects either (1) late closure of the $\mathrm{K}-\mathrm{Ar}$ system during progressive cooling of the pluton from above $700^{\circ} \mathrm{C}$ to below $300^{\circ}-350^{\circ}$ $\mathrm{C}$ or (2) the occurrence of a later thermal phase, during which the Ar-Ar system was reset in biotite but the $\mathrm{U}-\mathrm{Pb}$ clock was not reset in titanite. Slow, progressive cooling at $10^{\circ} \mathrm{C} / \mathrm{Myr}$ rate seems less likely than a late thermal input, because cooling rates would have to be unrealistically slow for a magma emplaced into an entirely solidified, and therefore much colder, upper crustal gneiss complex. Since the gneisses preserved their metamorphic fabric, temperatures of the gneisses during intrusion must have been below $300^{\circ} \mathrm{C}$. In consequence, the most likely interpretation for the age difference is to ascribe biotite resetting to a later thermal event causing temperatures between $300^{\circ}$ and $350^{\circ} \mathrm{C}$ within the Haihui granodiorite. Such reheating of the pluton was possibly caused by the magmatism responsible for the emplacement of the Donggu granite, as suggested by $97-98$ $\mathrm{Ma}{ }^{40} \mathrm{Ar} /{ }^{39} \mathrm{Ar}$ biotite ages for an exposure south of Haihui (Figure 9). However, further data are required to corroborate this idea.

\section{Discussion and Conclusion}

The tectonic-metamorphic-plutonic events recognized in the Lushan massif are significant for understanding the geological frame of SE China tectonics. The Late Cretaceous D3 event clearly belongs to the Yanshanian cycle. Cretaceous plutons deformed during or immediately after their emplacement are already well known in the area, for example, in the Wugongshan [Faure et al., 1996] or in the Dabieshan [e. g., Hacker et al., 1996; Eide et al., 1994; Faure et al., 


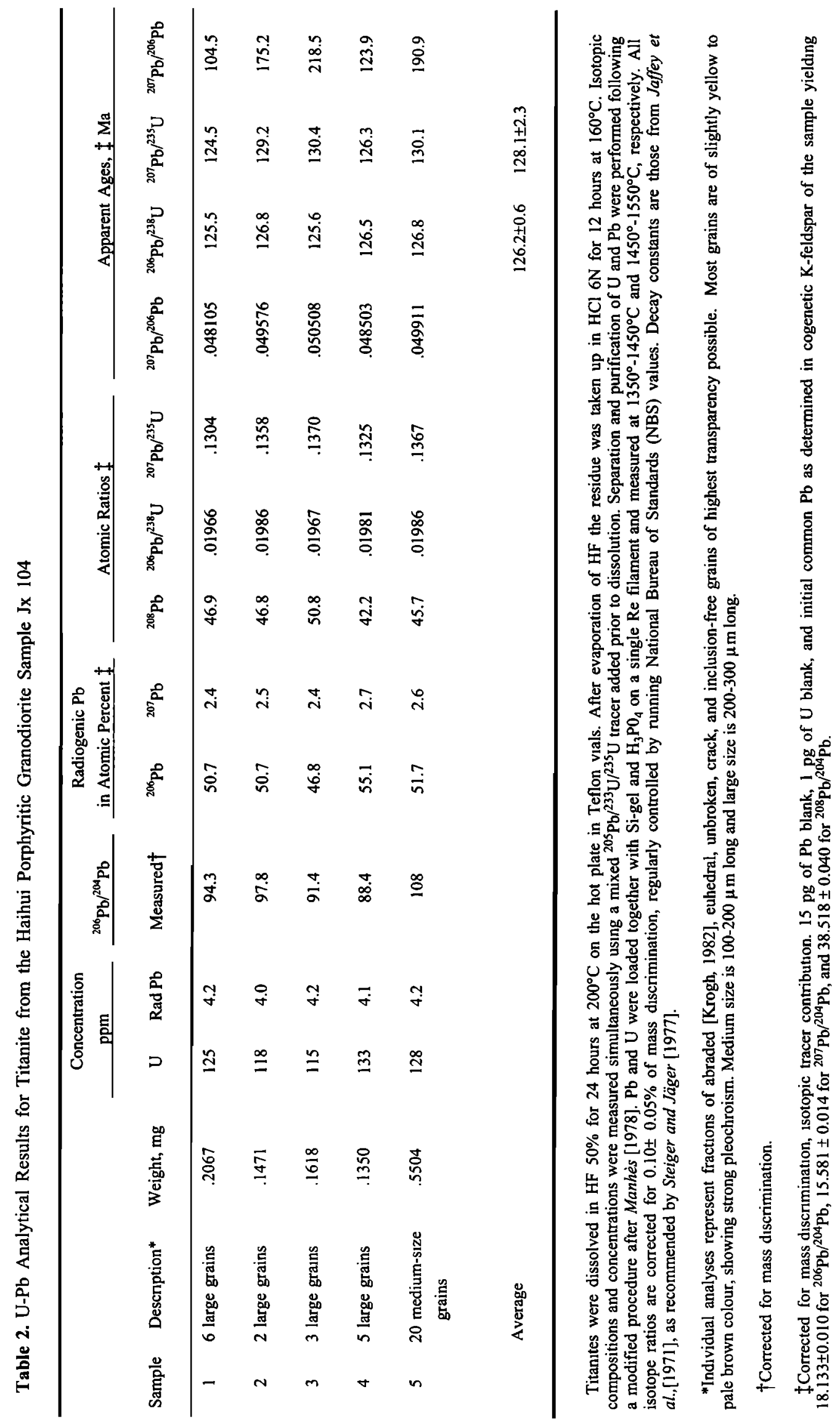




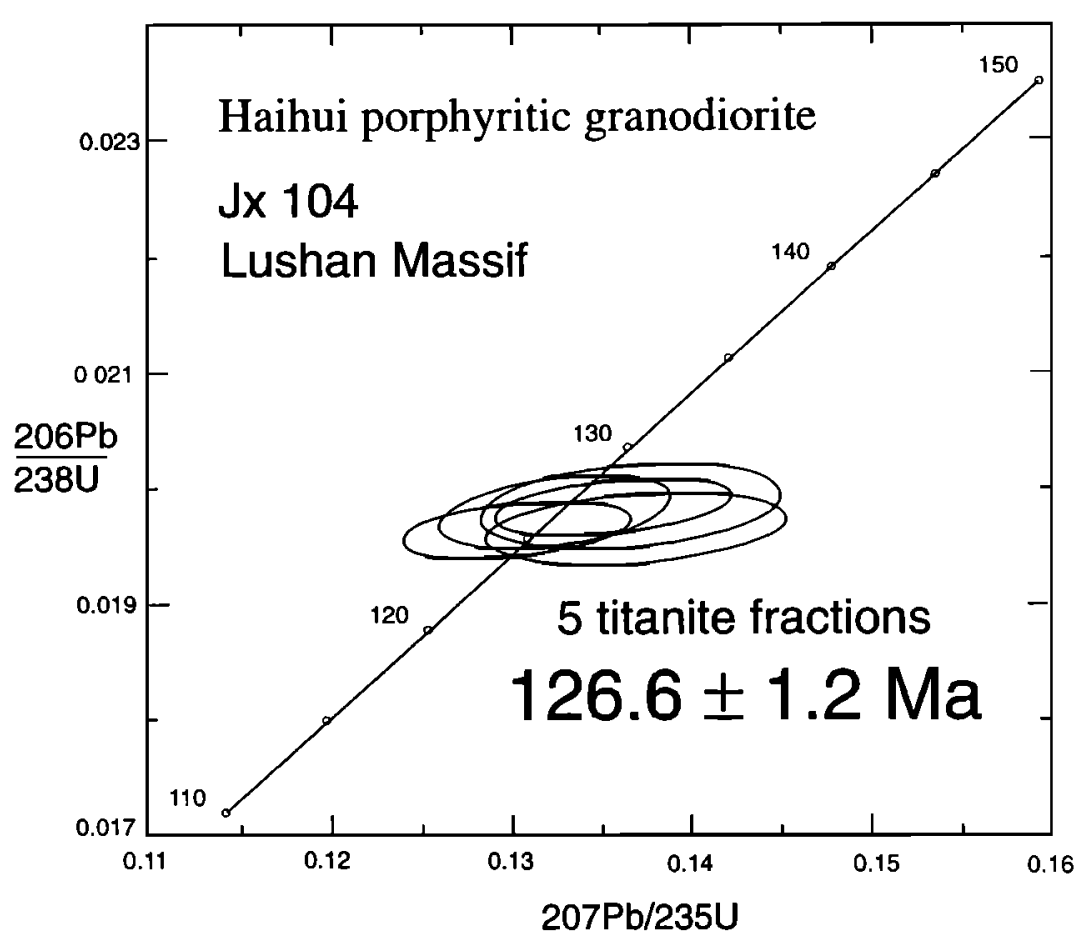

Figure 12. $\mathrm{U} / \mathrm{Pb}$ concordia diagram of titanite from the Haihui granodiorite (sample $\mathrm{Jx} 104$ located in Figure 9).

2000]. The question as to whether this deformation is a local event limited around some plutons or is a regional one corresponding to extensional tectonics is not uniquely answered by our data. However, Cretaceous plutons are widespread in SE Asia. Although they are generally related to westward subduction of an oceanic plate, intrusion extends several hundred kilometers inland from the subduction zone. While a general discussion on the geodynamic setting of the Mesozoic magmatism along the eastern margin of Eurasia is beyond the scope of this paper, we suggest that in the Cretaceous, SE China experienced regional extensional tectonics as supported by the continental red beds deposited in grabens [e.g., Gilder et al., 1991; Qiu et al., 1991]. This conclusion is also in agreement with the Late Cretaceous normal motion proposed along the southern end of the Tan-Lu fault [Mattauer et al., 1991].

The D2 event corresponds to the formation of the Lushan anticline. NW-SE shortening is coeval with NE-SW stretching and vertical shortening. Folding occurred after the development of the intermediate temperature-intermediate pressure metamorphism. The age of folding provided by the circa $127 \mathrm{Ma} \mathrm{U} / \mathrm{Pb}$ age (Early Cretaceous according to Odin [1994] timescale), of the syntectonic Haihui granodiorite demonstrates that D2 also belongs to the early stage of the Yanshanian cycle. A similar Early Cretaceous age (circa 132 Ma) from a granite mylonite associated with a normal fault bounding a granodioritic pluton is known in the Wugongshan (Figure 1) [Faure et al., 1996].

The top-to-the-NW D1 deformation is the most difficult to interpret. A very simple explanation would be to consider that D1 is a northwestward thrusting coeval with a medium temperature-medium to high pressure metamorphism. However, several lines of evidence do not support this view.
Firstly, quartz $c$ axis fabrics indicate a deformation temperature lower than that given by metamorphism. Secondly, D1 emplaces younger Paleozoic to Sinian rocks upon older Proterozoic slate, micaschist, and gneiss. Such a contact does not contribute to thickening the sequence but rather the converse: the tectonic boundary between Sinian rocks and Proterozoic metamorphics is "a subtractive contact" responsible for thinning of the pile as shown by the disappearance of Proterozoic rocks east of the massif. In the east, where Sinian rocks directly overly the metamorphics (Figure 2), the Proterozoic sequence has been faulted out. Therefore thrusting is unable to account for superposition of younger rocks upon older.

Another interpretation is preferred here, where we consider the medium temperature-medium pressure metamorphism to be coeval with the Dx event that predated the Dl deformation. Because of the intensity of the DI and D2 events, the Dx deformation associated with the metamorphism has been erased. This interpretation is supported by the observation that staurolite, garnet, and kyanite are retrogressed and cataclased during D1. In this model the northward verging "subtractive" D1 deformation corresponds to an extensional decollement of the Sinian and Paleozoic rocks, within already metamorphosed rocks. Such decollement surfaces are also described in the nearby Jiulingshan and Wugongshan [e. g., Zhu et al., 1987; Faure et al., 1996, 1998; Lin et al., 1998] and also in the Dabieshan [Mattauer et al., 1985, 1991, personal observations] (Figure 1).

At the present state of knowledge the age of D1 is unknown, but since Sinian and Paleozoic rocks are involved, D1 is probably related to a Mesozoic event, belonging either to the Triassic (Indosinian) orogeny or to the Cretaceous (Yanshanian) orogeny. Relation of D1 to the early Paleozoic 
$\mathbf{N}$

S

a

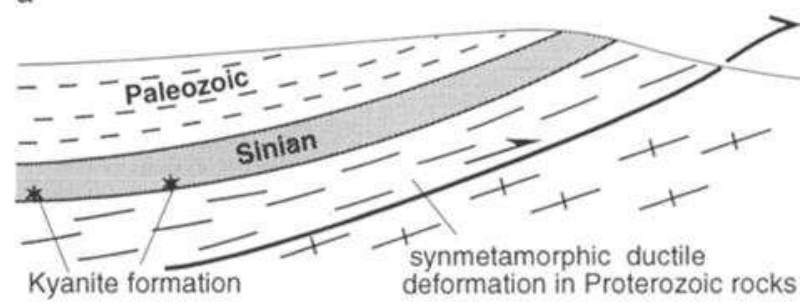

b ent

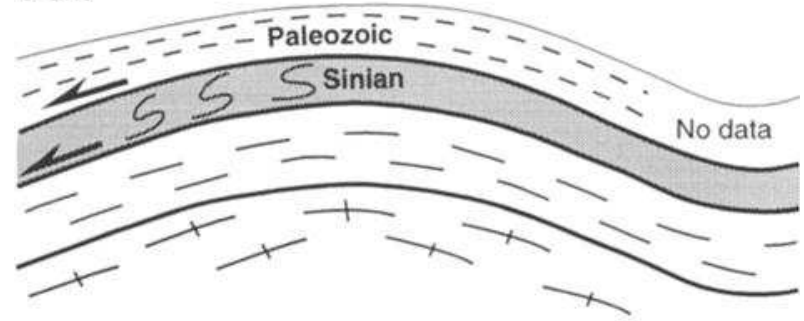

c

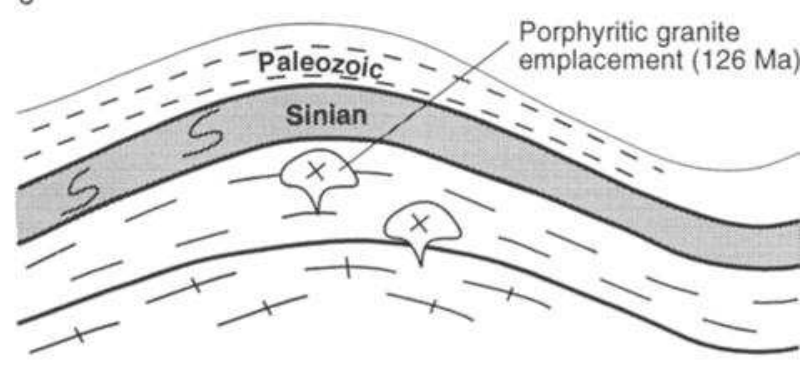

d

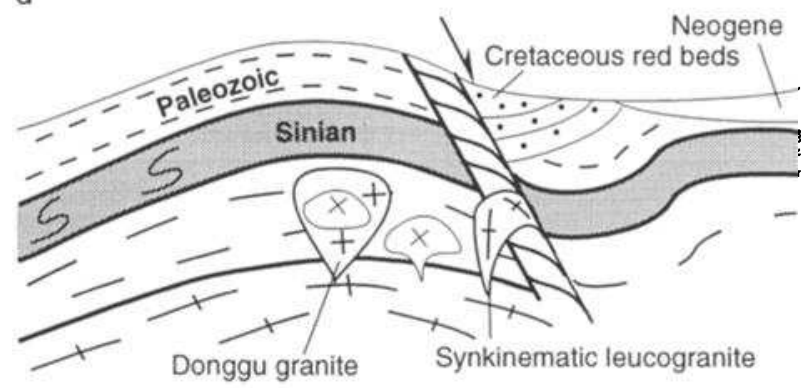

Figure 13. Interpretative model of the tectonic-metamorphic events in the Lushan massif. (a) Dx Permian-Triassic? event: synmetamorphic thrusting. (b) D1 Triassic-Cretaceous ? event: decollement. (c) D2 event: Early Cretaceous folding. (d) D3 event: Late Cretaceous normal faulting.

(Caledonian) orogeny is unlikely since, conversely to many places in SE China, a Late Devonian unconformity does not exist in the north part of Jiangxi Province. The time interval between the Dl deformation and the Dx metamorphism appears to be a key point for the understanding of the tectonic evolution of the Lushan massif. Obviously, most protoliths of the metamorphic rocks are older than Sinian, but the metamorphic continuity between micaschists and kyanitebearing metapelites implies that Dx formed in Mesozoic times. However, Dx may have formed either long before D1 (for instance during Triassic, if DI is Cretaceous) or immediately before Dl; that is to say, during the same orogenic event. It is worth noting that all geochronological or structural works dealing with Dabieshan recognize a major tectonic event in Triassic time [e. g., Mattauer et al., 1985; 1991; Okay et al., 1993; Ames et al., 1996; Eide et al., 1994; Hacker et al., 1996]. Although still highly speculative, the latter possibility is chosen below to develop a tectonic model in which Dl occurred during the Triassic Indosinian orogeny.

A possible general evolution would be to consider that during the Triassic convergence leading to the Dabieshan orogen, the south China plate, which corresponds to the southern foreland of this orogen, also experienced thrusting and crustal shortening. At depth, intermediate- to highpressure metamorphism (Dx) develops in Proterozoic and Sinian rocks during shearing responsible for crustal slicing (Figure 13). As in the Dabieshan, such thrusts are not recognized in the field [e. g., Okay et al. 1993], but the existence of a blind thrust is supported by seismic data [Wang et al., 1997]. Blocking of thrusting induces the upward buckling of the thrust surface in a dome-like structure, and when the critical shear strength is reached, the Sinian to Paleozoic cover rocks could slide downward on both limbs of the anticline (Figure 13). By comparison with other domal structures in north Jiangxi Province, such as Wugongshan or Jiulingshan where decollements are dated to Triassic time [Lin et al., 1998; Faure et al., 19981, in Lushan massif, D1 could also likely have a Triassic age. The exhumation of the deep metamorphic part of the Lushan massif is partly assisted by the proposed D1 decollement and by Cretaceous extensional tectonics. During the Early Cretaceous, emplacement of the Haihui granodiorite would have enhanced the domal shape of basement high (Figure 13). Lastly, the SE side of the antiform was cut by a ductile normal fault coeval to leucogranite intrusion (Figure 13).

\section{Appendix}

During this study, both ${ }^{40} \mathrm{Ar}{ }^{39} \mathrm{Ar}$ step-heating of mineral bulk separates and laser probe dating of single grains were used following analytical procedures that have been previously described [McDougall and Harrison, 1988; Monié et al., 1994, 1997]. For bulk separates, samples have been irradiated in the Grenoble nuclear reactor (France) together with different flux monitors including McClure Mountain homblend-1 (520.4 $\pm 1.7 \mathrm{Ma})$ and Heidelberg Bergell Biotitel $(24.21 \pm 0.32 \mathrm{Ma})$. For this reactor the following correction factors for argon nuclear interferences were applied: $\left({ }^{36} \mathrm{Ar} /{ }^{39} \mathrm{Ar}\right)_{\mathrm{Ca}}=0.000289,\left({ }^{39} \mathrm{Ar} /{ }^{37} \mathrm{Ar}\right)_{\mathrm{Ca}}=$ 0.000676 , and $\left({ }^{40} \mathrm{Ar} /{ }^{39} \mathrm{Ar}\right)_{\mathrm{K}}=0.0307$. Samples used for laser probe dating have been irradiated with the same monitors in the McMaster nuclear reactor (Canada). The correction factors were the following: $\left.{ }_{38}{ }^{36} \mathrm{Ar} / \mathrm{Ar}\right)_{\mathrm{Ca}}=0.000254,\left({ }^{39} \mathrm{Ar} /{ }^{37} \mathrm{Ar}\right)_{\mathrm{Ca}}$ $=0.000651,\left({ }^{40} \mathrm{Ar}{ }^{39} \mathrm{Ar}\right)_{\mathrm{K}}=0.0156$. Only the errors on total ages and plafeau dates include the uncertainty on the monitor age and its $\mathrm{Ar} /{ }^{39} \mathrm{Ar}$ ratio. Laser analyses were conducted on separated single grains using a laser probe operating in the semipulsed mode. The analytical device consists of : (1) a multiline continuous 6-W argon-ion laser with two main wavelengths of 488 and $514 \mathrm{~nm}$; (2) a beam shutter for selection of exposure times, typically $30 \mathrm{~ms}$ for spot fusions; (3) optical lenses to focus the laser beam down to a minimum impact diameter of $20 \mu \mathrm{m}$; (4) a small inlet line for the 
extraction and purification of gases; and (5) a Mass Analyser Products 215-50 noble gas mass spectrometer equiped with a Nier source and a Johnston Mesh Multiplier 1 electron multiplier. Each analysis involves $5 \mathrm{~min}$ for gas extraction and cleaning and $15 \mathrm{~min}$ for data acquisition. System blanks were evalugted every three experiments and ranged from $310^{\circ}$ $\mathrm{cm}$ for Ar to $610^{-14} \mathrm{~cm}$ for ${ }^{36} \mathrm{Ar}$.
Acknowledgments. Field work has been founded by the National Science Foundation of China for M. Faure, Y. Sun and P. Monié. The French Ministère des Affaires Etrangères and Minıstère de l'Education Nationale are acknowledged for providing the $\mathrm{Ph} D$. scolarship for $W$ Lin and for supporting the exchange visit of Y. Sun in France E Eide is acknowledged for her help in improving the first draft of this paper.

\section{References}

Ames, L, G Zhou, and B Xiong, Geochronology and isotopic character of ultrahıgh-pressure metamorphism with implications for collision of the Sino-Korean and Yangtze cratons, central China, Tectonics, 15, 472-489, 1996

Corfu, F, Multistage zarcon and titante growth and inhentance in an Archean gneiss complex. Winnipeg River Subprovince, Ontano, Earth Planet Scr Lett, 141, 175-186, 1996

Dahl, $P$ S . The effects of composition on retentivity of argon and oxygen in homblende and related amphiboles $A$ field-tested empincal model, Geochim Cosmochim Acta, 60, 3687. 3700,1996

Eide, $E$ A, M O McWilliams, and $J$ G Liou, ${ }^{40} \mathrm{Ar} /{ }^{39} \mathrm{Ar}$ geochronology and exhumation of high-pressure to ultrahigh-pressure metamorphıc rocks in east-central China, Geology, 22, 601604, 1994

Etchecopar, A, Kinematıc model of progressıve deformation in polycrystalline aggregate, Tectonophysics, 39, 121-139, 1977

Faure, M, Y Sun, L Shu, P. Monté, and J Charvet, Extensional tectonics withın a subduction-type orogen. The case study of the Wugongshan dome (Jiangxi Province, SE China), Tecionophysics, 263, 77-108, 1996

Faure, $M, W$, Lin, and $Y$ Sun, Doming in the southern foreland of the Dabieshan (Yangtse block, China), Terra Nova, 10, 307-311, 1998

Faure, M, W Lin, $L$ Shu, and U Scharer, Tectonics of the Dabieshan (E. China) and possible exhumation mechanısm of ultra highpressure rocks, Terra Nova, in press, 2000.

Gilder, S, G R Keller, M. Luo, and P C Goodell, Timing and spatial distribution of nfting in Chına Tectonophysics, 197, 225-243, 1991

Gilder, S A, P H Leloup, V Courtillot, Y. Chen, S R Coe, X Zhao, W. Xıao, N. Halim, J.-P Cogné, and $R$ Zhu, Tectonic evolution of the Tancheng-Lujıang (Tan-Lu) fault via Middje Tnassic to early Cenozoic paleomagnehc data J Geophys Res, 104, 15,365-15,390, 1999

Hacker, B R, X Wang, E A Elde, and L Ratschbacher, The Qinling-Dabie ultrahighpressure collisional orogen, in Tectonic Evolution of $A$ sia, edited by $\mathrm{A}$ Y $\mathrm{in}$ and $\mathrm{T} \mathrm{M}$ Harrison, pp 345-370, Cambndge Unıv Press, New York, 1996

Hames, W E., and J T. Cheney, On the loss of ${ }^{40} \mathrm{Ar}$ from muscovite dunng polymetamorphism, Geochım. Cosmochim Acta, 61, 3863-3872, 1997.

Harrison, T M, Diffusion of ${ }^{40} \mathrm{Ar}$ in homblende Contrib Mineral. Petrol, 78, 324-331, 1981

Harrison, T M, I Duncan, and $L$ McDougall, Diffusion of ${ }^{40} \mathrm{Ar}$ in biotıte Temperature, pressure and compositional effects, Geochm Cosmachum. Acta, 49, 2461-2468, 1985

Hibbard, M J , Deformation of incompletely crystallized magma systems Granitıc gneisses and their tectonic implications, $J$ Geol, 95 . 543-561, 1987
Hsu, K J, J Ll, H Chen, Q. Wang, S Sun, and A M C Sengor, Tectonics of south China Key to understanding West Pacific geology, Tectonophysics, I83, 9-39, 1990

Jaffey, A H, K. F. Flynn, L. E, Glendenın, W C Bentley, and $A$ M. Essling, Precision measurement of half-lives and specific activities of ${ }^{238} \mathrm{U}$ and ${ }^{235} \mathrm{U}$, Phys Rev, 4. 1889-1906, 1971

Jiangxi Bureau of Geology and Mineral Resources (JBGMR), Regional Geology of Jiangxı Province, Geol Publi. House, Beljıng, 921 pp 1984.

Kurschner, D L , M A Cosca, $\mathrm{H}$ Masson, and J C. Hunziker, Staircase ${ }^{40} \mathrm{Ar} /{ }^{39} \mathrm{Ar}$ spectra of finegraned white mica Timing and duration of deformation and empirical constraints on argon diffusion, Geology, 24, 747-750, 1996

Krogh, T. E, Improved accuracy of U-Pb zircon ages by the creation of more concordant system using air abrasion technique, Geochim Cosmochim. Acto, 46, 637-649, 1982.

Law, R D, Crystallographıc fabrics. A selective review of their applications to research in structural geology, in Deformation Mechanisms, Rheology and Tectoncs, edited by R. J Knipe and E H Rutter, Geol Soc Spec. Publ, 54, 335-352, 1990 .

Lin, W, M. Faure, $Y$ Sun, and $P$ Monié, Compression et extension permo-tnasique (Indosinienne) dans l'avant-pays du Dabıeshan (Chine du Sud), RST 98, Soc Géologique de France, Brest, France, 1998

Manhès, G., J-F Minster, and C J Allègre, Comparative uranium-thonum-lead and rubidium-strontium study of the Sant Sévenn amphoterite- Consequence for early solar system chronology, Earth Planet Sct Lett, 39, 14-24, 1978

Mattauer, M., P Matte, J Malavieille, P Tapponnier, $H$ Maluskı, $Z X u, Y ~ L u$, and $Y$ Tang, Tectonics of the Qinling Belt. Build-up and evolution of eastern Asia, Nature, 3/7, 496-500, 1985

Mattauer, M, P Matte, $\mathrm{H}$ Maluskı, Z Xu, O Zhang, and $Y$ Wang, La limite Chine du NordChine du Sud au Paléozoĩque et au Trias Nouvelles données structurales et radıométrıques dans le massıf du Dabıeshan (chaine des Qinling), C. RAcad Sct, Ser II, 312, 12271233. 1991

McDougall, I, and T M Harrison, Geochronology and Thermochronology by the ${ }^{40} \mathrm{Ar} r^{39} \mathrm{Ar}$ Method, 212 pp, Oxford Univ. Press, New York, 1988

Monıé, P, J. Soliva, M Brunel, and H Maluski, Les cisallements mylonitiques du granite de Millas (Pyrénées, France): Age crétacé ${ }^{40} \mathrm{Ar} /{ }^{39} \mathrm{Ar}$ et interprétation tectonique, Bull Soc Geol. Fr. 165, 559-571, 1994

Moniè, P., R. Caby, and $M$ H. Arthaud, The Neoproterozoic brasılıano orogeny of northeast Brazl ${ }^{40} \mathrm{Ar} /{ }^{39} \mathrm{Ar}$ ages and petro-structural data from Ceara, Precambrian Res, 81, 241-264, 1997

Odın, G S., Geological tıme-scale, $C R$ Acad $S c ı$ Ser. II, 3/2, 59-71, 1994

Okay, A, A M C Sengor, and M Satır, Tectonıcs of an ultrahigh-pressure metamorphic terrane The Dabieshan/Tongbaishan orogen, Chına, Tectonics, I2, 1320-1334, 1993

Onstott, TC, C M. Hall, and D York, ${ }^{40} \mathrm{Ar} /{ }^{39} \mathrm{Ar}$ thermochronometry of the Imataca complex Venezuela, Precambrian Res, 73, 255-291, 1989.

Qiu, Y., Q. Wu, X $J_{1}, J L_{1}, H$ Zhong, and $Z$ Sheng, Meso-Cenozolc taphrogeny and dispersion in the continental margin of southeast China and adjacent seas, Tectonophysics, 197. 257-269, 1991.

Steiger, $\mathbf{R} H$, and E Jager, Subcommission on geochronology: Convention on the use of decay constants in geo- and cosmochronology, Earth Planet Scr. Lett., 36, 359-362, 1977

Wang, $C, Z$. Ding, $Z$ Song, Q Wu, J Zheng, and $X$ Zhang, Study of crustal structure of Dabieshan from the analysis of the $S$-wave velocity, Acta Geophys. Sinica, 40, 54-63 1997.

Zhang, $\mathrm{L}-\mathrm{S}$, and $\mathrm{U}$ Scharer, Inherited $\mathrm{Pb}$ components in magmatıc tıtanite and their consequence for the interpretation of U-Pb ages, Earth Planet. Sa Leti., 138, 57-65, 1996

Zhu, $Z$, J. Ye, and $K$ Yang, On thrust-nappe and gliding-detachment on both sides of MufushanJiulingshan uplift and asymmetrical tectonic architecture of mountains (in Chinese), Earth Scl , 12, 503-510, 1987

M. Faure and W. Lin, Institut des Sciences de la Terre d'Orléans,

Université d'Orléans, 45067 Orléans Cedex 2, France.

(Michel.Faure@univ-orleans.fr)

P. Monié, Laboratoire de Géochronologie, Géochimie et Pétrologie, UMR

5567, UMI, Pl. E.-Bataillon, 34095 Montpellier Cedex, France.

(monie@dstu univ-montp2 fr)

U. Schärer and L. Zhang, Laboratoire de Géochronologie, UMR 7578,

Université Paris 7, and IPG-Paris, 2 Place Jussieu, 75251 Paris Cedex 2,

France. (scharer@ipgp.jussieu.fr)

Y.Sun, Department of Earth Sciences, Nanjing University, Nanjing, 210093 China

(Received May 25, 1999,

revised December 8, 1999 ,

accepted January 28, 2000) 